\title{
ÍNIGO DE LOYOLA Y LOS MERCADERES CASTELLANOS DEL NORTE DE EUROPA. LA FINANCIACIÓN DE SUS ESTUDIOS EN LA UNIVERSIDAD DE PARÍS*
}

\author{
POR
}

\author{
Francisco de Borja Medina
}

Institutium Historicum Societatis lesu, Roma

\section{Resumen}

Estudio documental del contexto económico en que se desenvolvio la acción del estudiante f́nigo de Loyola para recaudar fondos en las plazas mercantiles del norte de Europa a fin de financiar sus estudios en París. El antor subraya la importancia de no reducir esas actividades a mero aspecto de la vivencia de la humildad y la pobreza del santo, sino fruto además de las relaciones mercantiles internacionales de la familia de Ínigo, en parte como aspecto de la economía vascongada de su época.

\begin{abstract}
Documented study about the economic context in which the student Inigo de Loyola worked in order to get funds to finance his studies in Paris. The author remarks that it is important not to reduce these activities to a simple aspect of Ifigo's humbleness and poorness; it was also a fruit of the international commercial relations of Inigo's family, as a part of the Basque economy of that epoch.
\end{abstract}

* Hace algún tiempo, publiqué una aproximación a este mismo tema: «Ignazio di Loyola e il finanziamento degli studi a Parigi» La Civiltà Cattolica 143 (7 gennaio 1995) 41-54. En la elaboración del presente ensayo, agradezco al profesor Dr. D. Miguel A. Ladero Quesada, de la Real Academia de la Historia, la lectura del manuscrito y sus oportunas observaciones, asi como a los profesores Drs. Don Hilario Casado Alonso y Don Ángel Garcia Sanz, de la Facultad de Ciencias Económicas de la Universidad de Valladolid, sus valiosas sugerencias.

Hispania, del Mediterráneo al Atlantico Hispania Sacra 51 (1999) 


\section{ÍNIGO DE LOYOLA ¿MENDIGO EN FLANDES?}

Entre los hechos relacionados con la vida de Íñigo López de Loyola después de su conversión, cobra especial relieve su conducta mendicante a partir de la vela de armas ante Nuestra Señora de Monserrate y del cambio de vestidos con un mendigo camino de Manresa. Vive de limosna aquí y en Barcelona y así hace su peregrinación a Jerusalén. A su vuelta, comienza sus estudios en la ciudad condal y los prosigue en las Universidades de Alcalá de Henares y Salamanca, siempre dependiendo de la buena voluntad de bienhechores o de la mendicidad. Esta conducta continuará con sus viajes a las plazas mercantiles del norte de Europa, entre los años 1529-1531, en busca de recursos para sufragar sus estudios en la Universidad de París.

Pero, al centrar los hagiógrafos de Ignacio de Loyola la atención en su porte de mendigo y en los valores espirituales de la pobreza y de la humildad que ella comporta, olvidan otros aspectos no menos importantes. Así las noticias que los documentos coetáneos a los hechos ofrecen sobre el tema de los viajes ínigo a las plazas norte europeas se interpretan en el sentido de un puro ejercicio de pobreza por parte del peregrino ${ }^{1}$.

Esta interpretación corre el riesgo de desvirtuar y empobrecer la figura de Ínigo y su sentido de los valores humanos al no destacar, quizás lo bastante, sus dotes naturales y sus conocimientos prácticos que, luego, a la luz de su experiencia, inspirarán la organización económica de los colegios para la formación intelectual, humana y religiosa de los estudiantes de la Compañía de Jesús.

Por otra parte, pienso que no se ha prestado la debida atención al entorno económico de f́nigo, al que no fue ajeno ni por familia ni por su formación (de 1507/8 a 1516) en la corte del Rey Católico como continuo comensal de Juan Velázquez de Cuéllar, uno de los dos Contadores Mayores de Hacienda de Castilla. Tampoco se han estudiado suficientemente sus viajes a las plazas del norte de Europa en el contexto de la historia económica del periodo ni el sistema empleado, por Îñigo, en la recaudación de fondos y su administración en París.

J. Pérez Villanueva ha ilustrado, hace algunos años, diversos aspectos de la vida en esas ciudades de la Europa septentrional en tiempo de Íñigo ${ }^{2}$, pero creo que aún haría falta prestar mayor atención a las características de la coyuntura económica en la que se inscriben los viajes ignacianos y la posible relación de

1 Véase, p.ej., RICARDo GARCIA VILLOSLADA San Ignacio de Loyola. Nueva biografia (Madrid 1986, BAC Maior 28) 312

2 J. PÉrez VILlanUeVa Ignacio de Loyola en el Norte de Europa en Ignacio de Loyola en la crisis del siglo XVI Congreso Internacional de Historia. Madrid, 19-21 nov. 1991 (Bilbao-Santander 1993) 255-281

Hispania, del Mediterráneo al Atlántico Hispania Sacra 51 (1999) 
los Loyola con Flandes a través del mercado del hierro, como dueños de ferrerías y exportadores del metal.

Precisamente, en abril de 1529, año del primer viaje de Íñigo a Flandes, Martín García de Oñaz, señor de Loyola, había concertado la exportación de 154 quintales de hierro semielaborado, «fierro banda platina ... buenos e marchantes e bien entallados tales que sean de dar e de tomar de mercadero a mercadero», puestos en el puerto de la Rentería de Bedua, en la jurisdicción de Cestona, o en los de Eguileta, Arrasate o cualquier otro puerto, «pesados en qualesquiera dellos, quitos de todos derechos, falta e peso con el dicho quintal para el día y fiesta de Navidad que prim[er]o será»? ${ }^{3}$.

En enero de este mismo affo, 1529, el Emperador habilitaba, a expensas de Sevilla, nueve puertos para el comercio directo con Indias, entre ellos Bilbao y San Sebastián ${ }^{4}$. Coincidía con la intensificación del comercio con Flandes e Inglaterra, entorpecido por la guerra entre Francisco I y Carlos V.

No puede descartarse a priori que ínigo de Loyola conociera a mercaderes, armadores y marinos guipuzcoanos y vizcaínos con intereses en Europa septentrional. Iñigo pertenecía, por su madre, Marina Sayz de Licona, al linaje vizcaino de los Licona de Lequeitio emigrados en el s. XV a Ondarroa. De su antepasado Martín García de Licona, cabeza de linaje de esta villa, se decía que era «mercadero mucho rico», probablemente maestre de nao, lo cual no empecía a su condición de hidalguía. Se puede afirmar que los Parientes Ma-

${ }^{3}$ Escritura firmada en la Casa y Solar de Loyola el 7 abril 1529, ante el escribano Juan Martínez de Alzaga, por la que el sefior de Zarauz, Juan Ortiz de Gamboa, como principal deudor, y sus fiadores, otorgaban a Martín García de Oniaz, señor de Loyola, dicha cantidad. Archivo Histórico de Loyola (AHL) 1-1-1 ' n. 16 . Véase mi trabajo frigo Lopez de Loyola: probable estancia en Sevilla (1508 y 1511) y su reflejo en los Ejercicios Archivum Historicum Societatis Iesu (AHSI) 63 (1994) 3-76, 32-34. La rentería o casa lonja de Bedua era propiedad de la casa-solar de este nombre, a cuyos sefiores se pagaban derechos de servicio. Tenía una buena situación para la descarga de la vena traída de Vizcaya para el suministro de las ferrerías de la Provincia y ofrecía comodidad para el peso, almacenaje, carga, descarga y exportación del hierro trabajado en dichas ferrerlas, algunas de las cuales pertenećan al señor de Loyola. PABLO DE GOROSÁBEL Noticia de las cosas memorables de Guipúzcoa 1. Bilbao (Biblioteca de la Gran Enciclopedia Vasca) ${ }^{2} 1967$, pp. 129-132. Los Loyola habían posé́do en un tiempo o en otro, las ferrerías de Ubisusaga e Ibaihederraga, en Beizama, y la de lbarola en Aranaz. En 1535, todavía funcionaba la de Ubisusaga: Monumenta Historica Societatis Iesu (MHSI) Fontes documentates de S. Ignatio de Loyola. Documenta de S. Ignatii familia et patria, iuventute, primis sociüs (Ed.C. de Dalmases, S.I., en adelante Fonses doc.) Roma 1977, 81486

4 El emperador, en Toledo, a 15 enero 1529. DIEGO DE ENCINAS Cedulario Indiano, 1596. (repr. facsimilar). Estudio e indices de ALFONSO GaRcia GaLlo. Madrid 1946, 4 vol. IV, 133-136. Años después se revocó esta orden: Felipe II en Madrid 1 y 21 diciembre 1573. Ibidem 135-137. MANUEL JOSEF DE AYALA Diccionario de Gobierno y Legislación de Indias III. De Capellán a Comercio Libre (Edic. y estudios de MARTA MILAGROS DEL VAS MINGO) Madrid, 1988, voz Comercio pp. 254-55. ANTONIO GARCIA-BAQUERO GONZÁlez La Carrera de Indias: Suma de la Contrata. ción y Oceano de Negocios. Sevilla 1992, 35 
yores eran mercaderes en el sentido de comerciar con el hierro forjado en sus propias ferrerías, como el señor de Loyola ${ }^{5}$.

En la segunda mitad del siglo XV, Juan García de Licona y Juan Pérez de Licona, hermanos del abuelo de ínigo, Martín García de Licona (el Doctor Ondarroa, del Consejo Real), eran copropietarios por igual de la nao Santiago (de la que el primero era maestre) y participaban en el transporte marítimo entre Brujas, Sevilla y el Mediterráneo occidental, tradición que continuaron, en la generación siguiente, los primos hermanos de la madre de Íníigo ${ }^{6}$. En 1478, Martín García de Licona, vasallo mareante, tenía su nao Santiago fondeada en Cádiz y cubría las rutas de Génova y Flandes. En 1489, prestó servicio, como homiciano, en el asedio y toma de Baza, donde fue herido. En 1509, al mando de su nao de 140 toneles, con 27 tripulantes, formó parte de la armada de Pedro Navarro en la jornada de Orán 7 .

La tradición familiar materna pasó al primogénito de los Loyola. De 1493 a 1496, en que falleció en Nápoles, Juan Pérez de Loyola, hermano mayor de Íñigo, sirvió con su propia nao como capitán de mar en la escuadra de Vizcaya del mando de f́nigo de Artieta ${ }^{8}$. Por otra parte, otro de los hermanos mayores de ínigo, Ochoa Pérez de Loyola, había formado parte del séquito que acompañó a Flandes y de vuelta a Castilla, a la Princesa Juana, luego reina. En Flandes, donde se detuvo de 1504 a 1506 , se habría, sin duda, relacionado con maestres de naos y mercaderes vascongados que pululaban por Brujas y Amberes?.

${ }^{5}$ F. DE AROCENA El abuelo matemo de San Ignacio en Problemas históricos guipuzcoanos en la vida de San Ignacio. San Sebastián 1956, 9-10. D. DE AREITIO Nuevos datos sobre el abuelo materno de San Ignacio de Loyola. AHSI 26 (1957) 218-229

6 SABINo AGUIRRE GANDARIAS Los Likona de Bizkaia medieval, parientes maternos de finigo de Loiola en La Compafla de Jesús en Bizkaia [edición bilingüe vascuence-castellano]. Sala de exposiciones del Archivo Foral de Bizcaia. Diciembre 1991, 21-46; 33-40. Sobre el pleito entre ambos hermanos, entablado en Brujas (julio 1452) por la nao Santiago que poseían a medias, véase del mismo autor: Los Likona de Ondarroa durante el siglo XV (con nuevos documentos) Ondarroa 1992, 7-20. Para otros detalles sobre la actividad transportista de Juan García de Licona y Martín García de Licona, de Ondarroa, en el Mediterráneo, especialmente con Génova, véase JACQUES HeERS Le commerce des Basques en Méditerranée au XV' siècle (d'après les Archives de Gênes) Bulletin Hispanique 57 (1955) 292-324, 300 nota 3, 313 nota 4, 315316320 . Y en general ISABEl MUOARTEGUI EGUIA Las actividades de intermediacion: Transporte y Comercio del País Vasco marfímo a finales del siglo XV en El Pueblo Vasco en el Renacimiento (1491-1521) pp. 107-133

7 AgutRRE Gandarias Los Likona de Bizkaia medieval 36-37. En 1486, Martín García de Licona, estaba en Flandes donde, en una riña en Ramua (¿Amemuyden?), dio muerte a Juan de Valmaseda. Obtuvo perdón real en 1488 y, de nuevo, cuando la toma de Baza.

${ }^{8}$ F.B. MEDINA Su politica mediterranea Ignacio de Loyola y el mar. Revista de Historia Naval (Instituto de Historia y Cultura Naval. Armada Española) XIII, n. ${ }^{\circ} 50$ (1995) 11-56; 14-18

9 Testamento de Ochoa Pérez de Loyola, 16 febrero 1508. MHSI Fontes doc. 185-194. Entre sus acreedores aparece un «Orozco ... defunto ... vascongado» (Ibidem 187). En 1504, un tal Fernando de

Hispania, del Mediterráneo al Atlántico Hispania Sacra $\$ 1$ (1999) 
No hay constancia documental de la relación directa de Íñigo con sus paisanos, o parientes, con negocios en el norte de Europa, pero sí respecto de los mercaderes castellanos de aquellas plazas. Los viajes de Íñigo entre 1529-1531 se encuadran en el contexto de la coyuntura económica de esas plazas y del protagonismo de los mercaderes de la «nación española» en su impulso y desarrollo. Por otro lado, interesa advertir el periodo del año en que înigo emprende sus viajes de cuestación y el empleo de los instrumentos financieros habituales en la tramitación y administración de los recursos obtenidos.

Este será el objeto del presente trabajo: el estudio de la relación de Íñigo López de Loyola con los mercaderes castellanos del norte de Europa, el método seguido y los instrumentos empleados en la financiación de sus estudios en la Universidad de París y el influjo que esta experiencia tuvo en la ordenación económica de los colegios de la Compañía de Jesús.

\section{ÍNIGO, UNIVERSITARIO PARISIENSE}

Íñigo eligió para sí la condición de los estudiantes pobres, pero escogio, para prepararse al ejercicio del ministerio sacerdotal, las universidades más prestigiosas de Europa. Comenzó por las de Alcalá de Henares y Salamanca y acabó en París, la más famosa universidad europea, donde se gradú de Maestro en Artes. Más tarde, en Italia, a la espera de sus compañeros parisienses para emprender la peregrinación a Jerusalén, se instaló en la reputada Bolonia para terminar en su Universidad los estudios teológicos, s6́lo que el clima malsano le hizo encaminarse a Venecia, donde los concluyó.

Su itinerario no fue lineal ni entró de un golpe en sus planes: tuvo que pasar por la experiencia de otros «golpes» que lo fueron encaminando hacia París. La decisión vino dada, no tanto en razón de la calidad de los estudios parisienses, como del apostolado directo que no le permitían ejercitar las autoridades eclesiásticas en España, hasta no concluir sus estudios de teología.

Después de una experiencia universitaria de seis años, de los que cuatro, en París, Iñigo consideraba la Universidad parisina la mejor de la Cristiandad. Así lo aseguraba a su hermano Martín, en 1532, proponiéndole el envío de su hijo Millán a París donde aprendería, en cuatro años, más que en otras universidades en seis.

Orozco era, en Brujas, cónsul de la nación de Vizcaya: CARMELo ECHEGARAY Indice de documentos referentes a la Historia Vasca que se contiene en los Archivos de Brujas. San Sebastián, 1929, p. 89-90. 
«... en ninguna parte de la christiandad —decía- hallaréis tanto aparexo como en esta uniuersidad; para su costa, maestro y otras indigencias de estudio, creo bastarán cinquenta ducados cada af́o, bien prouehidos. Pienso que en tierra estraña, diuersa y fría, no querréis que vuestro hijo pase necesidad, que el estudio le pueda impedir, según mi juicio. Si miráis la costa, en esta uniuersidad ganáis con él, porque más fruto hará aquí en quatro años, que en otra, que yo sepa, en seis; y si más me alargase, creo que no me apartaría de la verdad» 10 .

Años después, desde Roma, repetiría el mismo juicio a su sobrino Beltrán de Oñaz y Loyola, con el mismo motivo del envío de Millán a París:

«Aquí he sabido del buen ingenio de vuestro hermano Emilián, y deseosso de estudiar. Holgaría que mucho mirásedes y pensásedes en ello; y si mi juizio tiene algún valor, yo no lo emuiaría á otra parte que á Parf́s, porque más le haréis aprouechar en pocos años, que en muchos otros en otra uniuersidad; y después es tierra donde más honestidad y virtud guardan los estudiantes; y por lo que de mi parte me toca en dessear su mayor provecho, yo querría que este camino tomasse, y lo mesmo comunicássedes á su madre; y donde Araoz no fuere para allá, aurá personas de authoridad y buena vida que ternán mucho cuydado dél»11

Con esta convicción nacida de la experiencia, años adelante, Íñigo implantará en los colegios de la Compañía de Jesús un orden y método de estudios (Ratio Studiorum) basado en el «modo» de París, Lovaina y Alcalá ${ }^{12}$.

\section{EL SOPORTE ECONÓMICO}

Antes de encaminarse a la ciudad del Sena, había aprendido, por experiencia, que no podía vivir de limosna y estudiar al mismo tiempo. Así, su viaje solo y a pie ${ }^{13}$ lo hace desde Barcelona, donde se detuvo unos tres meses y

${ }^{10}$ Ignacio a Martín García de Oñaz. Fin de junio 1532. MHSI Sancti Ignatii de Loyola Societatis lesu fundatoris epistolae et instructiones. 12 vol., Madrid 1903-1911. Reimpr. 1964-1968. (En adelante Epplgn) I, 78.

11 Ignacio a Beltrán de Oñaz y Loyola. Roma, [24?] septiembre 1539. MHSI Epplgn I, 149. Antonio de Araoz era sobrino de Magdalena, madre de Millán. Sería, poco después, recibido por Ignacio de Loyola en la recién fundada Companía de Jesús y contribuy6, de modo decisivo, a implantarla en España.

12 cf. Polanco (ex comm.) a L. de Mendoza. Roma 20 octubre 1553. MHSI Epplgn V, 553. Sobre el método, ver G. CODINA MIR Aux sources de la pédagogie des Jésuites. Le umodus parisiensis». Roma 1968 (=Biblioteca Instituti Historici Societatis Iesu [BIHSI] 28)

${ }^{13}$ Acta P. Ignatii cap. VII, n. ${ }^{\circ} 72$, cap. VIII n. ${ }^{\circ}$. 73. MHSI Fontes narrativi de S. Ignatio de Loyola et de Societatis Iesu initiis (Ed. CÁNDIDO DE DALMASES) 4 vol. Roma 1943-1965 (en adelante Fontes narr.) 1, 463. Para lectores menos especializados, cf. San Ignacio de Loyola. Obras. Edición manual. Madrid s' 1991 (=BAC 86). L. Autobiografta (Ed. CÁNDDO DE DALMASES) pp. 73-177; 144-145.

Hispania, del Mediterráneo al Atlántico

Hispania Sacra 51 (1999) 
contó, para la financiación de sus estudios en París, con la generosidad de sus antiguas conocidas y devotas que, durante sus estudios de gramática en la ciudad condal (1524-1526), le habían ayudado con sus limosnas y habían recibido de él ejemplos y consejos. Esta vez, le proveyeron lo mejor que pudieron para el viaje, pero fñigo procuró que el dinero para sus estudios se lo giraran sobre París. Confiaba que pudieran continuar este socorro, en especial Agnès, o Inés Pasqual, que le había alojado en su casa en esos años, e Isabel Roser (en realidad Ferrer, mujer de Joan Roser) que había sufragado los gastos de los estudios cursados bajo el maestro Jerónimo Ardévol ${ }^{14}$.

Íñigo partió de Barcelona a primeros de enero de 1528 y llegó a París el 2 de febrero siguiente ${ }^{15}$. Aquí un mercader le entregó 25 escudos por una cédula de cambio de Barcelona. De este modo, pudo alojarse, con otros españoles, en una casa vecina al colegio de Monteagudo (Montaigu) donde repasó Humanidades, durante unos dos cursos, como estudiante externo, o martinet ${ }^{16}$. En el supuesto de no tratarse de un anacronismo en vez de ducados, sino de escudos del sol (écus d'or au soleil) o coronas, la cantidad entregada correspondía, más o menos, a la mitad del gasto anual de un estudiante en París bien provisto para su costa, maestro, libros y otras atenciones, para no pasar necesidad que impidiese el estudio «en tierra estraña, diuersa y fría». Recuérdese que ésta había sido la estimación presupuestaria de Ínigo para su sobrino Millán ${ }^{17}$, después de una experiencia de cuatro años y en época de carestía y alza de precios inaudita que se prolongó de 1531 hasta marzo 1532, el año más caro de que había memoria ${ }^{18}$.

La apreciación de Íñigo pone de manifiesto la penuria a que estaba expuesta la mayoría de los estudiantes de París y él entre ellos. Como datos comparativos, un estudiante pago, en 1532, 24 coronas por sólo su alojamiento en una casa particular y, en 1533, el Profesor Regio, Johann Sturm, exigía 30

$14 \mathrm{~J}$. A. DE POLANCO Sumario de las cosas más notables que a la institución y progreso de la Companfa de Jesus tocan (en adelante POLANCO Sumario), cap 2 n. ${ }^{\circ} 45$. MHSI Fontes narr. I, 177. ID. De vita P. Ignatii et Societatis eius initiis (en adelante POLANCO Vita) cap. VI, n. ${ }^{\circ} 49$. MHSI Fontes narr. II, 553. Ignacio a Inés Pasqual. París, 13 junio 1533. MHSI EppIgn I, 91 nota 3

is Ignacio a Inés Pasqual, París, 3 marzo 1528.MHSI Epplgn I, 74

${ }^{16}$ Autobiografía cap. VIII, $\mathrm{n}^{\circ} 73$

17 Ignacio a Martín García de Oñaz. Fin de junio 1532. MHSI Epplgn I, 78. Por comparación con los cambios de la libra navarra, establecidos por la pragmática de 1524 , se deduce que la corona francesa, couronne au soleil, o écu d'or au soleil, equivalía a unos 352 maravedís castellanos: Jost YANGUAS Y MIRANDA Diccionario de antigüedades del reino de Navarra 3 tomos. Pamplona ${ }^{2} 1964$, voz Moneda II, 192. De ser ese el cambio en 1527, f́igo habría recibido unos 23 ducados.

18 MÁRIO BRANDÃo A Inquisição e os profesores do Colégio das Artes I, Coimbra 1948, 123 128; GeORg SChURHAMmeR Francisco Javier. Su vida y su tiempo. Tomo I Europa 1506-154I [Pamplona 1992] (en adelante SCHURHAMMER Javier) 205 
coronas a los pensionistas alemanes y suizos alojados en su casa ${ }^{19}$. Este era también el caso de Francés —o Francisco- de Xavier, porcionista de Santa Bárbara, y el de su sobrino Juan de Xavier, por el que, Miguel de Jassu, Señor de Xavier, hermano de Francisco, había prometido pagar 30 ducados/año a su huésped, el Maestro Caparroso -el navarro Charles Marzilla-- que lo tuvo alojado de 1538 a $1541^{20}$.

Las becas, o bolsas, del colegio de Santa Bárbara, donde estudió Ínigo de octubre 1528 a abril 1535 , eran de 30 ducados, pero generalmente sólo cubrían manutención y hospedaje ${ }^{21}$. En 1526, el rey de Portugal, Juan III, a petición de Diogo de Gouvea, su agente diplomático en Francia y Principal del colegio, lo había dotado con 50 becas anuales de esta cuantía. El anuncio oficial del rey portugués al Rector de la Universidad (15 enero 1528) sobre la fundación de becas en Santa Bárbara coincidió con la llegada de fñigo a París ${ }^{22}$.

El valor de la bolsa, librada por el factor real de Amberes, era el doble de la primera asignación manuelina. Antaño, los estudiantes portugueses de París que frecuentaban el colegio de Monteagudo habían gozado de ciertas ayudas del rey Don Manuel, libradas asimismo en Amberes por su factor. Entre 1510 y 1517 , recibían de 15 a 20 cruzados/año. En 1519, aumentó la asignación a 35 cruzados. Los nobles percibían, en esta misma fecha, hasta 100 crazados/año ${ }^{23}$.

Otros estudiantes parisienses contaban con menos. En 1526, la bursa deI colegio de Mans, vecino de Santa Bárbara, era de 24 libras tomesas al año, equivalente a 12 coronas, o sea, la mitad de los 25 escudos de Ínigo ${ }^{24}$.

Por estos mismos años, la asignación anual del hijo de una familia de mercaderes burgaleses acomodados para sus gastos podía ser, como ocurría con los nobles portugueses, unos 100 ducados al año. Era el caso de Juan Alfonso de

\footnotetext{
19 SCHURHAMMER Javier I, 205 nota 78

20 SCHURHAMMER Javier I, 103 nota 50, 310 nota 134

21 SCHURHAMMER Javier I, 205

22 BRANDÁ O Colégio das Artes I 1547-1555, Coimbra 1924, p. 26. ID A Inquisiçāo I, 151-154 160-163. SCHURHAMMER Javier I, 102-103 146. Para la personalidad de Gouvea: Ibidem 129-136

23 J.A. GORIS Etude sur les colonies marchandes méridionales (Portugais, Espagnols, Italiens) à Anvers de 1488 a 1567. Contribution a t'histoire des débuts du capitalisme modeme. Louvain 1925, 222-223. BRANDÃo A Inquisiçāo I, 113-116. El cruzado adquirió valor respecto de la plata: de 380 reaes en 1510-1514 y 392 reaes en 1514-1517, subió a 400 rs en el ajuste de 1517 , por lo que las cantidades consignadas a los becarios nobles equivalían practicamente a unos 100 cruzados. V. MAGALHĀES GODNHO Os Descobrimentos e a economia mundial II, ${ }^{2} 1985,66$ 89-91.

24 SCHURHAMMER Javier 103. Todavía, 30 anios más tarde, en el Acta de fundación del colegio de Santa Bárbara, después de dejarlo los portugueses, Robert Dugast creó (19 noviembre 1556) siete bolsas, tres mayores (principal, procurador y capellán) y cuatro menores para estudiantes. A los tres primeros asigno 50 libras tomesas al año (=25 escudos) y, a los segundos, 25 libras (=12 escudos, 1 libra) «pour leur vivre, alimentation et entretenement» y 200 más para la bolsa común. J. QUICHERAT Histoire du Sainte-Barbe. Collège, Communauté, Institution. 3 vol. Parrs 1860-1864, III, 342-344
}

Hispania, del Mediterráneo al Atlántico

Hispania Sacra 51 (1999) 
Polanco, futuro secretario de Ignacio de Loyola en Roma ${ }^{25}$. En 1535, aparecía inscrito en la Universidad de París como iuratus ${ }^{26}$. En 1538, su bursa (bolsa), esto es, su gasto ordinario semanal deducido el alquiler de su cámara y el salario de su criado valía 7 sueldos parisienses, lo que lo colocaba entre los divitiores ${ }^{27}$.

\section{LOS VIAJES DE CUESTACIÓN A FLANDES}

fñigo confí sus 25 escudos en depósito, a uno de sus compañeros españoles que compartían alojamiento en la misma casa. La historia es conocida: el camarada gastó el dinero sin posibilidad de reintegrarlo. Por ello y debido, además, a los propios gastos, Íñigo, terminada la Cuaresma a mediados de abril de 1528, tuvo que abandonar la casa, albergarse en el hospital de SaintJacques, lejano del colegio, y mendigar. A esto se añadía que las lecciones comenzaban en Monteagudo a las 5 de la mañana y terminaban a las 7 de la tarde, mientras que Saint-Jacques no se abría hasta el amanecer y se cerraba a la caída del sol, por lo que, sobre todo en invierno, f̂ñigo perdía lecciones sólo podía asistir dos horas- y la mendicidad y la distancia no le dejaba tiempo para el estudio.

Como otros estudiantes sin recursos, Î́nigo buscó servir como fámulo, en algún colegio, a uno de los regentes para poder subsistir y estudiar, pero no encontró ninguno a pesar de intentarlo por medio de algunos conocidos y amigos, entre ellos, el bachiller Juan de Castro, socio de la Sorbona y estudiante de teología; un fraile cartujo con conocimiento de muchos maestros de París y un canónigo regular de San Víctor. Al fin, por consejo de un fraile español,

\footnotetext{
25 cf. Testamento de Gregorio de Polanco y Mará de Salinas, 26 marzo 1546. MHSI Polanci Complementa. Epistolae et commentaria P. Joannis Alphonsi de Polanco e Societate Jesu. 2 vol. Madrid 1916-1917. I, 489. Durante sus estudios de Teología, en Padua (1542-1546), recibía 100 ducados/año. Hasta esa fecha, sus padres habían gastado en sus estudios más de 300.000 maravedís (800 ducados) lo que supondría un gasto de 100 ducados anuales durante 8 años. Con licencia de sus padres, Polanco había vendido el oficio de la escritoría apostólica que gozaba en Roma, por valor de 1.000 ducados, para emplearlos en sus estudios teológicos y ayuda del incipiente colegio de la Compañía en Padua Ibidem. Gregorio de Polanco, regidor de Burgos, padre de Juan A., era uno de los grandes exportadores burgaleses de lana: MANUEL BASAS FERNÁNDEZ El consulado de Burgos en el siglo XVI Madrid 1963, 260

26 Ricardo G. VIlloslada La Universidad de Paris durante los estudios de Francisco de Vitoria O.P. (1507-1522) Roma 1938, 373-374 nota 3. «Juratus" se dice del estudiante que ha prestado juramento ante las autoridades universitarias poco antes de obtener los primeros grados en Artes. Ibidem.

${ }^{27}$ SCHURHAMMER Javier I, 309 nota 127. CHARLES THUROT De lorganisation de l'enseignement dans l'Université de Paris au Moyenne-Age Paris 1850 61-63. La bursa, que había que declarar bajo juramento, era la unidad de cuenta para el cálculo de las tasas académicas. El sueldo parisis valía un $20 \%$ más que el sueldo torness: la libra de París valía 25 sueldos torneses.
} 
cuyo nombre no se consigna, viajó a Flandes durante la Cuaresma de 1529 para solicitar ayuda economica a los mercaderes españoles que, segín le explicó el fraile amigo, solían darla con largueza a estudiantes en apuros ${ }^{28}$.

Gracias a los dineros de Flandes, Íñigo pudo continuar sus estudios con mayor comodidad y, para el $10^{\circ}$ de octubre de 1529, fiesta de San Remigio, obispo de París y comienzo de curso en la Universidad, se instaló en el colegio de Santa Bárbara donde comenzó el curso de Artes. Compartía la habitación con el regente Juan de la Peña, el saboyano, pastor de ovejas en su niñez, Pedro Fabro (Le Fèvre), y el noble navarro Francisco de Xavier, hermano de Miguel de Jassu, señor de Xavier.

Dado el buen resultado de su gestión, ínigo volvió a Flandes durante los veranos de 1530 y 1531 , por un periodo de dos meses cada vez, antes del comienzo del curso por San Remigio. Sabía dónde y cuándo encontrar recursos abundantes, pues deseaba ayudar también a sus compañeros apurados. Recomía las plazas mercantiles más importantes de los Países Bajos -Brujas y Amberes- que contaban con una nutrida colonia de mercaderes españoles. El último año, 1531, atravesó el Canal de la Mancha y pasó a Londres obteniendo, en su colecta, un mayor rendimiento que los años precedentes. A partir de este año y, hasta su salida de París, en abril 1535, no tuvo necesidad de reiterar sus viajes ya que los mercaderes le giraban sus asignaciones voluntarias en letras sobre sus corresponsales de París ${ }^{29}$.

\section{LA COYUNTURA ECONOMICA}

Los viajes ignacianos (1529-1531) se insertan en la coyuntura del periodo y coinciden prácticamente con el inicio de la época de esplendor del mercado burgalés (1525-1550). El primer viaje - Cuaresma 1529- se realiza en el marco de la reactivación económica de Flandes, en especial de Amberes, después de casi una década de relativo estancamiento (1521-1529), debido al enfrentamiento armado de Francisco I y el Emperador, que terminará con la firma de Paz de las Damas, o de Cambray (agosto 1529). La pugna Valois-

\footnotetext{
${ }^{28}$ Autobiografía cap. VIII, nn. 73-76. Para la posible ruta a Flandes, véase PÉrEZ VILLANUEVA $259-261$

29 Autobiografia cap. VIII, n. ${ }^{\circ} 76$. POLANCO Vita, cap. VI, nn. 54-55. MHSI Fontes narr. II, 556 558. Autobiografia de San Ignacio de Loyola en SAN IGNACIO DE LOYOLA Obras completas. Tomo I. Autobiografia y Diario espiritual. Introducción, notas y comentarios deI P. VICTORIANO LARRAÑAGA, S.I. Madrid 1947 (=BAC 24) (en adelante LARRAÑAGA) 316-321 notas 13-15. PéreZ VILLANUEVA 255-281; 256-261
}

Hispania, del Mediterráneo al Atlántico Hispania Sacra 51 (1999) 
Habsburgo paralizó el comercio internacional y, como resultado, entorpecí el mercado anversano del dinero que estaba en sus comienzos ${ }^{30}$.

El relanzamiento económico de los Países Bajos, y de Amberes en particular, estuvo ligado al aflujo de los metales preciosos a Sevilla -que dotó a Castilla de una dimensión político-económica nueva- y a la actividad comercial de los mercaderes castellanos. El eje financiero Sevilla-Medina del Campo-Bilbao-Amberes dependía de la llegada de las flotas a Sevilla con la plata americana y de su distribución a los mercados europeos a través de las ferias de Brabante ${ }^{31}$.

Como resultado de la inyección de plata americana procedente de Sevilla, Amberes recibió un nuevo impulso. En 1531, el mismo año en que Íñigo realizó su último viaje a los Países Bajos -prolongado, en esta ocasión, hasta Inglaterra-, la ciudad del Escalda inauguró el nuevo edificio de su Bolsa y se erigió prácticamente en capital financiera de Europa, centro neurálgico que irradiaba a Inglaterra, Alta Alemania y Lyon. Sus múltiples actividades financieras se centraban, sobre todo, en los cambios y depósitos, constituyendo los cambios la principal operación ${ }^{32}$.

\section{LA «NACIÓN ESPAÑOLA»}

Los mercaderes de los reinos de España establecidos en las plazas mercantiles de los Países Bajos eran, en ese tiempo, los más numerosos frente a los de las otras naciones. Asentados principalmente en Brujas, se habían organizado en hermandades, corporaciones o universidades - «gildes»- y erigido sus

\footnotetext{
30 Véase, p. ej., HERMANN VAN DER WEE The Growth of the Antwerp market and the European Economy (fourteen-sixteen centuries) II. Interpretation, Louvain 1963, pp. 144-150; H. CASADO ALONso El comercio intemacional burgalés en los ss. XV y XVI. Actas del V Centenario del Consulado de Burgos. I Simposio internacional «El Consulado de Burgos». Burgos 1994, p.188-190

${ }^{31}$ ENRIQUE OTTE Sevilla plaza bancaria europea en el siglo XVI en Dinéro y Crédito (Siglos XVI al XIX). Actas del Primer Congreso Internacional de Historia economica (Madrid-VillalbaSegovia, 21, 22 y 13 de marzo de 1977) (ed. ALFONSO OTAZU) Madrid 1978, pp. 89-112

32 F. BRAUDEL Civilisation matérielle, économie et capifalisme, XV - XVIIT siecle. 3. Le temps du Monde (París 1979) 124-129. VAN DER WEE pp. 177-182 199-202. En el quinquenio 1521-1525, bajó enormemente la legada de plata a Sevilla. De la cifra global del periodo 1503-1560, corresponde a este quinquenio (1521-1525) un $0,35 \%$ frente al $2,58 \%$ del quinquenio anterior (1516-1520) y $2,70 \%$ y $4,29 \%$ respectivamente de los dos quinquenios siguientes $(1526-1530 ; 1531-1535)$ que coinciden con los afios de finigo en París. R. CARANDE Carlos $V$ y sus banqueros. 3 vol. (Barcelona $\left.{ }^{4} 1990\right)$ 1. La vida económica en Castilla (1516-1556), 240-241. Para las crisis cíclicas de Flandes y Brabante por este tiempo: CHARLES VERLINDEN Crises économiques et sociales en Belgique à lépo. que de Charles Quint en Charles Quint et son temps. Coloques internationaux du Centre National de la Recherche Scientifique. Paris 30 Septembre - 3 Octobre 1958. París 1959, pp. 177-190
} 
respectivos consulados por «naciones»: Aragón-Cataluña, Castilla-León, Vizcaya y Navarra. Estos consulados eran filiales de las corporaciones de mercaderes de sus respectivas «naciones»: el de Castilla-León del Consulado de Burgos, el de Vizcaya y el de Navarra del Consulado de Bilbao y el de Aragón-Cataluña del Consulado de Mar de Barcelona. Junto a éstos, se encontraban los portugueses dedicados al comercio de la especiería.

Al tiempo de las visitas de Íñigo de Loyola, se mantenían, en Brujas, los consulados de Castilla y de Vizcaya. El de Aragón-Cataluña había emigrado definitivamente a Amberes en 1527. La «nación» de Castilla englobaba a los súbditos del rey de Castilla al sur de Ebro, particularmente a los burgaleses, el grupo dominante por su número y poder ${ }^{33}$. El término burgalés comprendía también a los otros mercaderes castellanos «a quienes les bastaba ser ricos para que les llamasen burgaleses» ${ }^{34}$. Por estos años, había una mayor participación de mercaderes de otras ciudades castellanas en el comercio internacional, también en el sector laneró, como el caso de Segovia ${ }^{35}$.

La nación de Vizcaya agrupaba a los mercaderes, armadores y marinos, al norte del Ebro: Condado de Vizcaya, provincias de Guipúzcoa y Álava y «costa de la mar de España» hasta Galicia inclusive (exceptuadas las Cuatro Villas: Castro, Laredo, Santander y San Vicente, que posibilitaban la salida de Castilla al Cantábrico) ${ }^{36}$. Navarra formó parte de la nación de Vizcaya hasta 1530 , año en que los mercaderes navarros solicitaron del emperador, como conde de Flandes, tener consulado en Brujas al igual que las otras naciones de España ${ }^{37}$. Los andaluces, al tiempo de los viajes de Íñigo, se consideraban

33 Para la formación de las diversas «naciones» de España y el establecimiento de sus respectivos consulados, véase J. MARÉCHAL La colonie espagnole de Bruges, du XIV au XVT siecle. Révue du Nord (Faculté des Lettres de Lille) 35 (1953) 5-40; 14-18. Entre los mercaderes englobados en la nación de Castilla, se nombran los de Burgos, Sevilla, Toledo, Segovia, Soria, Valladolid, Medina, Logroño, Nájera, Navarrete. Para los andaluces véase más abajo.

34 GORIS 57-58. CARANDE 1, 240-241

35 CASAdo alonso 233

36 MARÉCHAL 16-18. Los mercaderes súbditos del rey de Castilla, conocidos en Brujas cono «nación de España», al constituirse en hermandad, gremio, o gilde y erigir su consulado, a medianos del siglo XV, tomaron esta denominación. Según el autor, debido a los intereses encontrados de vizcaínos y burgaleses, se escindió en dos «naciones» con sus respectivos consulados: Vizcaya y Castilla. Ésta siguí denominándose impropiamente «nación de Espaf́a», pero era conocida oficialmente como «nación de Castilla y León», «nación de los Castellanos», o «nación de Burgos». La de Vizcaya era también designada como «nación de Vizcaya, Guipúzcoa y costa de la mar de España» o simplemente «nation des costez d'Espaigne». Una sentencia del Gran Consejo de Malinas prohibi6 el uso de «nación de España» como sinónimo de hermandad o gilde de los mercaderes originarios del interior del reino de Castilla y ordenó reemplazarla por «nación de Castilla y León» Ibidem

${ }^{37}$ L. GULLIODTS VAN SEVEREN (ed.) Cartulaire de I ancien consulat d'Espagne à Bruges ... Premiere partie 1280-1550 2 vol. Bruges 1901-1902, I, 282 371. El 15 junio 1530, los mercaderes navarros, «Michiel Dardare, Michiel de Lumbier, Anthoine Daguerra (¿de Aguirre?), Jehan de la 
exentos de pertenecer a ninguna nación, por lo que no pagaban a ninguna de ellas las averias, a pesar de acarrearles otros inconvenientes. Requeridos notarialmente, en 1504, por los cónsules burgaleses de Brujas, al pago de las averías, los andaluces se negaron a ello, por acto notarial, en casa de Gonzalo de Sevilla, su principal representante en Berga (Berges-op-Zoom) ${ }^{38}$. Hay que notar que, el año anterior (1503), los Reyes Católicos habían establecido en Sevilla la Casa de Contratación de Indias que ejerció funciones de consulado hasta la erección, en la ciudad, de esta institución en $1543^{39}$.

Brujas había decaído comercialmente y cedido su puesto a Amberes, a donde habían emigrado, al final del siglo XV, todas la naciones a causa de las revueltas contra Maximiliano. A cambio de la vuelta a Brujas de los consulados españoles, los «échevins», o regidores municipales de la metrópoli flamenca, otorgaron a los mercaderes españoles la franquicia de estapla de las mercaderías españolas más importantes: lana, hierro, aceite, alumbre ${ }^{40}$.

Tanto Brujas como Amberes se encontraban dominadas por el comercio castellano y por los mercaderes burgaleses establecidos en ambas plazas y relacionados con sus corresponsales, agentes y factores en Castilla y, particularmente, en Sevilla, la plaza mercantil más importante del momento debido al tráfico con Indias y a la función distribuidora de sus productos, en especial de la plata, hacia los mercados norte europeos para los pagos de las transacciones de los particulares y para el desempeño de las deudas del Emperador con sus asentistas. Desde el siglo anterior, los burgaleses se dedicaban, con particularidad, a la contratación de la lana con factorías en Brujas, Londres, La Rochela, Nantes y Amberes. Negociaban en los Países Bajos mercancías españolas,

Ryette (¿de Larrea?)» presentaron, ante los «échevins» de la villa de Brujas, la solicitud de erección del propio consulado, como lo tenían las naciones $*$ Despaigne, Arragon et Biscayen, si así le placía a su Majestad imperial, como conde de Flandes. Suplicaban que se les otorgaran los mismos privilegios, franquicias y libertades que tenían los mercaderes de «Arragon et de la Cathaloigne». El emperador lo confirmó en Gante el 20 junio 1532 y la ordenanza de Brujas lo certifico el 8 agosto 1534. cf. ECHEGARAY 137-138.

38 MARÉCHAL 17, n. 6. BASAS 31-33. El 30 abril 1504, los cónsules de Burgos, Pedro de Salamanca, Alfonso Pesquier y Francisco de Covarrubias, por sus procuradores Gonzalo de Salamanca, Alfonso de Castro, Felipe Carrión y Francisco de Salamanca, emplazaron y requirieron, ante el notario apostólico Lienard Hughe, a los mercaderes andaluces, Pedro Pinto, Gonzalo de Sevilla y García Pérez, en Berges-op-Zoom, en casa del dicho Gonzalo de Sevilla, delante de los testigos Bernardino de Medina y Francisco de Angulo, mercaderes. Los andaluces dieron su respuesta negativa en 2 de mayo 1504. ECHEGARAY 82-84

${ }^{39}$ cf. FRANCISCO MORALES PADRON Historia de Sevilla. III.- La ciudad del Quinientos (Sevilla $\left.{ }^{3} 1989\right)$ 165-168

40 MARECHAL 21-22 
operaciones de crédito, armamento y flete de naves y contratos de seguros marítimos ${ }^{41}$.

Como índice de la actividad comercial en el sector lanero, en los años en que Íñigo visita Brujas (1529-1531) y en los posteriores hasta 1535, en que abandona París, la exportación lanera de Castilla a Flandes había supuesto 177 naves con 109.009 sacas y un ingreso en el consulado de Burgos, por concepto de avería, de casi millón y medio de maravedís $(1.455 .182)^{42}$.

Íñigo se dirige, pues, a los centros donde se encuentra el dinero y donde la moneda castellana está revalorizada en razón de la mejor ley del ducado (23 $7 / 8$ quilates) frente a las otras monedas europeas de peor ley (22 q.) y a la mayor abundancia dineraria en Castilla, causada por las remesas de Indias y su incidencia en el alza de precios ${ }^{43}$.

\section{EL MARCO DE LOS VIAJES IGNACIANOS: LAS FERIAS ${ }^{44}$}

En cuanto al tiempo del año, es interesante constatar que Íñigo emprende sus viajes coincidiendo con las ferias de pago de Brabante, donde había afluencia monetaria - y no fuera de ellas-y se daban cita mercaderes, maestres de naos, etc. de todas partes. Las ferias de Brabante se celebraban en las cuatro estaciones alternativamente en Amberes y Berga, o Berges (Bergen-opZoom): en Amberes, las de otoño, por San Bavón, o Sint-Baafs (1. octubre) (Baamismarkt) y la de Pentecostés (Sinksenmarkt) y, en Berga (Bergen-opZoom), las de invierno o «frías» (Koudemarkt) y las de Pascua Florida

41 Carande 1, 271-274. Braudel 3, 125. Para los asientos, o empréstitos, del Emperador sobre la plaza de Amberes: ID. Les emprunts de Charles-Quint sur la place d'Anvers en Charles-Quint et son temps 191-201.

42 CASADO Alonso 192194197 225. Faltan los datos de sacas exportadas en el ejercicio 1532/1533, pero dado el monto de avería de este año (174.095), semejante al siguiente (174.196), habría que añadir otras 23.400 sacas, lo que arroja un total de unas 132.400 sacas para el sexenio $1529 / 1535$.

${ }^{43}$ DOMINGo DE SOTO De Justitia et Jure libri decem Salamanca 1556, (De la Justicia y el Derecho ... edición facsimilar con su versión castellana ... Introducción histórica y teológico-jurídica por el Dr. P. Venancio Diego Carro.... Sección Teólogos Juristas. Vol. III. Instituto de Estudios Políticos. Madrid 1968, lib. VI, q. XII, a. 2, pp. 594-595. El ducado (375 maravedís) valía en Flandes 410 mrs. Ibidem. En 1535, un asiento capitulado por el secretario de emperador, Francisco de los Cobos, con mercaderes burgaleses puso el cambio sobre Amberes a $370 \mathrm{mrs}$. el ducado: a 37 placas (pacards) el ducado y $10 \mathrm{mrs}$ cada placa. CARANDE 3. Los caminos del oro y de la plata. Deuda exterior y tesoros ultramarinos, 174. Para la cuestión del mercado del dinero y su fluctuación en relación con las letras de cambio, R. DE ROOVER L'Evolution de la Lettre de Change XIV-XVIT' siecles, Paris, 1953, 48.49

44 Para toda la cuestión de los ciclos feriales y las conexiones de las ferias de pago de Castilla con las de Brabante, véase SơTO lib. VI, q. XII arts. 2 y 5, pp. 594603.

Hispania, del Mediterráneo al Atlántico Hispania Sacra 51 (1999) 
(Paaschmarkt). Duraban seis semanas y sus pagos 15 días. La de San Bavón se convocaba el segundo domingo después del 15 de agosto y las de Pentecostés 15 días antes de esta fiesta.

En estas ferias se efectuaban los pagos de las operaciones crediticias negociadas en las cuatro ferias castellanas, con las que guardaban relación: las dos de Medina del Campo de mayo (pagos 15 julio-10 agosto) y octubre (pagos mitad de diciembre-primeros enero), las intermedias de Medina de Rioseco (pagos 15 septiembre-10 octubre) y la de Villalón (pagos mitad CuaresmaPascua). El ciclo ferial se abría, en mayo, con las primeras ferias de Medina del Campo y se cerraba con las de Villalón, al año siguiente, por Pascua de Resurrección.

El intervalo de tres meses entre las ferias castellanas y sus correlativas brabanzonas suponía el tiempo necesario para que las letras liegaran cómodamente a Brabante y se pudiera preparar el numerario ${ }^{45}$. En el tiempo de Íñigo, los pagos de las cuatro ferias de Brabante se efectuaban en Amberes ${ }^{46}$.

En cuanto a las ferias escalonadas del condado de Flandes, en la época de los viajes de Ínigo, aún se celebraban las de Ypres ( 28 febrero- 29 marzo), Lila (15 agosto-14 sept.), Messines (1 octubre-1 noviembre) y las dos de Brujas: una que databa del siglo XIII (23 abril-22 mayo) y la segunda, otorgada por Maximiliano en 1509, del 5 de enero al 16 de febrero. Pero, en esta época, las ferias flamencas eran más bien regionales y las de Brujas, debido a su decadencia en favor de Amberes, se centraban en la lana castellana y en los paños ingleses que beneficiaban los centros artesanales flamencos ${ }^{47}$. La actividad comercial lanera con estos centros, así como con los existentes en los condados de

45 SOTo lib. VI, q. XII, arts. 2 y 5, pp. 593-599 602-610. CARANDE 1, 331-349. GORIS 113; ÉmIL COORNAERT Les Français et le commerce intermational à Anvers. Fin du XV'-XVf siecle, I-II. Paris 1961, I, 70 115-116. Esta era la norma: el cambista que entregaba el dinero en agosto, en las ferias de pago de Medina del Campo, cuyos cambios abrían en mayo, debía recibirlo en Amberes en las ferias de septiembre, o San Bavón (pagos 10 noviembre-fin de mes). De igual modo, las «frías» y las de Pascua de Resurrección, de Berga, con pagos desde la octava de la Candelaria (Lichtmis) -es decir, del 10 febrero- hasta fin de mes, la primera, y del 10 al 25 de mayo, la segunda, guardaban relación respectivamente con las ferias de Rioseco, de otoño y de Medina del Campo de octubrediciembre. Las de Amberes de Pentecostés, con pagos a partir de 10 agosto, estaban en conexión con los de Villakon de Cuaresma-Pascua.

46 FLORIS PRIMS Geschiedenis van Antwerpen. VI-A. Met Spanje 1555-17l5 Bruselas ${ }^{2}$ 1982, 293.

47 J-A van HOUTTE Les foires dans la Belgique ancienne. Recueil de la Societé Jean Bodin. vol. V La Foire, Bruxelles 1953, 175-207; 183-185. En el siglo XVI, ya no había noticias de la feria de Thourout (24 junio-24 julio) Ibidem. En 1509, los magistrados de Ruán rehusaron publicar, en su ciudad, esta feria: MicHEL MOLLAT Le commerce maritime normand d la fin du moyen age Paris 1952, 335. La feria «fría» de Brujas la cita Francisco de Vitoria en su dictamen a la consulta de 1532, hecha por Fray Juan Baptista, en nombre de los mercaderes españoles de Amberes: GoRIS 537 
Henao (Hainaut) y Artois, más cercanos a la urbe flamenca que a la brabanzona, fue una de las razones de la mayor presencia burgalesa en Brujas ${ }^{48}$.

En cuanto a Íñigo, el primer año (1529) marcha a Flandes en Cuaresma ${ }^{49}$. La razón parece obvia: ese año, el Miércoles de Ceniza, principio de la Cuaresma, cayó en 10 de febrero, exactamente el día señalado para el comienzo de los pagos de la octava de la Candelaria (Lichtmis), concertados en las ferias «frías» de Berga y en los pagos de otoño de Riosecos.

Los dos años siguientes, 1530 y 1531 , acude en verano cuando se efectúan los pagos del 10 agosto correspondientes a los contratos de las ferias de Pentecostés de Amberes y el cobro de los créditos vencidos de la feria de Villalón de Cuaresma-Pascua.

\section{LA PLAZAS DE CONTRATACIÓN.FRANCESAS}

Según el testimonio de Antonio de Araoz, Î̃igo solía visitar también Ruán y otras plazas de contratación francesas a donde acudían los mercaderes españoles para sus tratos 51 .

Ruán, capital de Normandía, en el estuario del Sena, ante-puerto de París, era la plaza portuaria francesa de mayor actividad mercantil, gran ruta comercial que unía la cuenca parisina a la costa fiamenca por la vía más directa marítimo-fluvial. En la ruta principal que unía a Sevilla con Amberes, el puerto ruanés servía de entrada de mercaderías castellanas hacia París y ciudades del interior y de salida de los productos bretones hacia los puertos del Cantábrico - San Sebástián, Bilbao, Santander - y a los del Atlantico: Lisboa, costa del Algarve, Lepe, Sanlúcar, Sevilla y Cádiz ${ }^{52}$. Sus dos ferias francas se celebraban, una por la Candelaria ( 2 febrero) y la otra por la Trinidad, fiesta dependiente de la Pascua que ocurre entre la segunda mitad de mayo y el mes de junio ${ }^{53}$. Los pagos de los productos contratados en feria se hacían generalmente en contante. De otro modo, los vencimientos de pago en Ruán se fijaban para el 25 marzo, 24 junio, 29 septiembre y 25 diciembre $^{54}$. Existía un estrecho

\footnotetext{
48 CASADO AlONSO 196-198

49 Autobiografta cap. VIII, nn. 73-76.

so SoTo lib. VI, q. XII, a. 5, p. 603. Este autor señala que, en Cuaresma, había otros pagos sin ferias.

st Quadam de P. Ignatio qua non sunt impressa (ca. 1582), nn. [5]-[6]. MHSI Fontes narr.. III, 207. En tomo a Ruán se encontraban otros puertos con presencia española, por ejemplo, Dieppe.

52 MOLlat 225 229. CASADO ALONSO 199

${ }^{53}$ MOLLAT 333-335

$\$ 4$ MOLLAT 390

Hispania, del Mediterráneo al Atlántico

Hispania Sacra 51 (1999)
} 
comercio con los Países Bajos, en especial con Amberes, cuyas ferias frecuentaban los mercaderes ruaneses ${ }^{55}$.

El comercio lanero ruanés dependía, en gran parte, de los reenvíos de los mercaderes burgaleses de Brujas que organizaban, asociados, sus expediciones a Ruán, donde se había establecído una cada vez más creciente colonia de mercaderes españoles, la mayoría, como en el caso de Brujas y Amberes, burgaleses de las mismas familias y linajes. Lo mismo ocurría en La Rochela o Nantes, donde también los ruaneses compraban la lana a los burgaleses ${ }^{56}$.

En Bretaña, Nantes, en la desembocadura del Loira, era otra de las plazas importantes de contratación en la que los mercaderes burgaleses dominaban los negocios. Servía dos rutas coincidentes con las anteriores: una hacia Sevilla y Cádiz y la otra a los puertos del Cantábrico. En éstos se organizaban, en marzo y septiembre, dos flotas, una con destino a Brujas y la otra a La Rochela y Nantes con productos laneros y siderúrgicos. La ciudad bretona quedaba algo más alejada de París por la ruta de Orleans y, por tanto, menos accesible a Ínigo por tierra, aunque no se excluye que pudiera utilizar el tráfico marítimo desde Ruán ${ }^{57}$.

\section{LOS MERCADERES DEL ENTORNO DE ÍNIGO}

Polanco y otros biógrafos coetáneos atribuyen el éxito de Ínigo en Flandes a sus dotes humanas y sobrenaturales con las que aficionaba a la piedad cristiana a aquellos con quienes trataba y se conciliaba su benevolencia, así como a la riqueza y generosidad de sus favorecedores ${ }^{58}$. Inigo, con sus conversaciones y género de vida, supo granjearse la estima y confianza amigable de los mercaderes españoles que le proporcionaron limosnas, le invitaron a su mesa y le hospedaron en sus casas. Según una antigua tradición trasmitida por los Bolandistas en el siglo XVIII, que recoge otra anterior, en Brujas lo aloj6 el burgalés Gonzalo de Aguilera y, en Amberes, el segoviano Juan de Cuéllar, con quien vivía el joven medinés Pedro Cuadrado ${ }^{59}$.

\footnotetext{
55 MOLLAT 182-189

56 MOLLAT 189-193 509-520; JULES MATHOREZ Notes sur les raports de Nantes avec l'Espagne Bulletin Hispanique 14 (1912)-15 (1913); COORNAERT I, 224;

57 J. REGLÀ La época de los tres primeros Austrias en J. VICENS VIVES Historia de España y América social y económica (Barcelona 1972) 3, 145. CASADO ALONSO 199. COORNAERT I, 311-313

58 POLANCO Vita, cap. VI, n. ${ }^{\circ}$ 54. MHSI Fontes narr. II, 557

59 Acta Sanctonum Iulii VII (Antuerpia 1731), p. 439. La noticias proceden de un manuscrito enviado por los jesuitas de Brujas a Roma en 1618: «Supplementa quædam ad historiam Collegii Brugensis». Para Cuéllar, ver GoRIS 612. FloRIS PRIMS Geschiedenis VI-B Met Spanje 1555-1715 .
} 
Pero, aun aceptando este don sobrenatural, habría que examinar también más a fondo la relación de ínigo con estos mercaderes a la luz de otros parámetros, por ejemplo su posición privilegiada, en la corte de Fernando el Católico, como familiar del Contador Mayor de Hacienda, Juan Velázquez de Cuéllar. Esta posición ventajosa le habría facilitado, no sólo el conocimiento de la organización de las finanzas de la Corona, sino también el contacto con el mundo de los mercaderes y banqueros de los cuales se servía aquella para su manejo. Sería extraño que fiñigo no hubiera visitado nunca las ferias castellanas, poco distantes de Arévalo, donde residía a temporadas, cuando no acompañaba la corte en el séquito de su protector Velázquez de Cuéllar. La corte itinerante del Rey Católico le habría llevado, de cualquier modo, a Burgos, Segovia y Medina del Campo, patrias respectivas de sus huéspedes y comensales de Brujas y Amberes: Aguilera, Cuéllar y Cuadrado ${ }^{60}$.

Por otra parte, habría que examinar las conexiones entre los miembros de familias de mercaderes, compañeros de Ínigo en París, y los de las plazas mercantiles de la Europa norteña. Esto me parece un punto importante, ya que ofrecería pistas para conocer con mayor precisión los contactos de Íníigo.

\section{Los «burgaleses» de París}

En cuanto a los mercaderes españoles instalados en la Villa de París, se sabe poco ${ }^{61}$. De los «burgaleses» conocidos de f́nigo, han ilegado a nosotros algunos nombres transmitidos por él mismo. Uno de ellos, el bachiller Juan de Castro, ya mencionado. A su regreso del primer viaje a Flandes, le dio los ejercicios espirituales, así como a otros dos: al toledano Pedro Peralta, bachiller sorb6nico como Castro, y al guipuzcoano Amador de Elduayen, colegial de Santa Bárbara. Como resultado, repartieron sus bienes a los pobres, incluso los libros, se pusieron a pedir limosna por las calles y pasaron al hospital de Saint-Jacques, poco después de haberlo dejado Íñigo. Los españoles llevaron muy a mal esta transformación, especialmente los burgaleses coterráneos de

Bruselas ${ }^{2} 1982,557-558$, atribuye a una leyenda la estancia de f́rigo en casa de Cuéllar, por suponer sus viajes de 1528 a 1530 , pero admite un posible viaje a Amberes.

60 Durante la gobernación de Fernando (1507-1516), que coincide con el servicio de fírigo en casa del contador velízquez, la corte paś largas temporadas en Burgos, la más dilatada de 6 agosto 1511 a 13 agosto 1512 , a la vuelta de Sevilla, donde se detuvo de $1 .^{\circ}$ febrero a 21 junio 1511 . En Segovia estuvo la corte, de pasada, en 1513 (1-2 nov.) y, con más detenimiento, en 1514 (22 mayo-17 julio) y 1515 (25 agosto-15 sept). En Medina, además de ser paso obligado, se detuvo la corte en 1513 (16 febrero-23 marzo) y 1515 (20 febr.-31 marzo) A. RUMEU DE ARMAS Itinerario de los Reyes Católicos 1474-1516 Madrid 1974, 369-409. Esto quiere decir que a finigo no le faltó oportunidad de tratar con mercaderes y banqueros y de estar al tanto del mundo de las finanzas.

6l COORNAERT I, 352-353

Hispania, del Mediterráneo al Athántico Hispania Sacra 51 (1999) 
Castro. Sacaron a los tres, a la fuerza, de Saint-Jacques y los hicieron volver al régimen ordinario de vida universitaria en sus colegios respectivos. El cambio de Peralta y Elduayen, despertó las furias del Dr. Pedro Ortiz, paisano del primero, y del Principal de Santa Bárbara, Nuestro Maestro Diogo de Gouvea, quien acusó a ínigo de haber vuelto loco a su colegial Amador. El caso se llevó ante el Inquisidor parisino, Mateo de Ory, que no tomó ninguna medida punitiva ${ }^{62}$.

\section{a. Juan de Castro y su linaje}

Juan de Castro, terminado su doctorado en París, predicó en Burgos, entró en la cartuja de Vall de Cristo, vecina a Segorbe -donde lo visitó Ínigo en 1535- y acabó sus días como prior de la cartuja de Porta Coeli (Valencia) en 1556, el mismo año de la muerte de Ignacio de Loyola en Roma ${ }^{63}$.

Los Castro formaban uno de los linajes de mercaderes burgaleses más extendidos, cuya red se extendía por toda Europa. Trataban de antiguo en Londres, Sandwich y Southampton, así como en Brujas, Gascuña, Tolosa y Lisboa ${ }^{64}$.

Para conocer el grado de parentesco de Juan de Castro con los Castro de Flandes y Londres se necesitaría un estudio genealogico más particularizado, ya que se repiten los homónimos. Pero, aunque importante para nuestro proposito, baste, por ahora, mencionar la presencia, desde años atrás, de este linaje en las plazas visitadas por Ífíigo en 1529-1531.

En Inglaterra, los Castro comerciaban desde mediados del siglo anterior. En los años 1470-80, Pedro y Diego de Castro llevaban, en Londres, substanciosos negocios de importación y exportación, tradición que continuó durante el siglo posterior. Pedro era el apoderado, en Londres, de su pariente y paisano, Fernando Castro de la $\mathrm{Hoz}^{65}$, cónsul de la Universidad de la Contratación de los Mercaderes de Burgos en $1483^{66}$.

Diego y Juan de Castro, apellidados los «Castro de Londres», desempeñaron oficios en el Consulado de Burgos: el primero, cónsul en 1498-1499 y, el segundo, prior en $1547-1548^{67}$.

\footnotetext{
62 Autobiografia, cap. VIII, nn. 75 77-78 81. POLANCO Sumario cap. $2 .^{\circ}$, n." 49 MHSI Fontes narr. I, 178-180

${ }^{63}$ Autobiografia n." 78 nota 7 . LARRANaGa 315 nota 11,325 nota 17,327 nota 21, 431-434,

64 W.R. CHILDS Anglo-Castilian Trade in the Late Middle Ages Manchester 1978215

65 CHILDS 224.

66 BASAS 107

${ }^{67}$ BASAS Apéndice I 267-268
} nota 21 
El nombre de Juan de Castro se repite. En 1511, un Juan de Castro (¿el de Londres?) y Alonso de Astudillo eran diputados del Consulado burgalés «para el Condado de Flandes e Inglaterra e Roán e Bretaña y otras partes de Francias ${ }^{68}$. En 1522, el mismo Juan de Castro (o su homónimo), establecido en Londres, actuaba de factor de los Sevilla (Çiville) de Ruán, amigos del Principal de Santa Bárbara, Diogo de Gouvea, agente del rey Juan III de Portugal, por cuya causa pasaba temporadas en la plaza normanda ${ }^{69}$.

En 1524-1525, otro Juan de Castro (o ¿el mismo?) desempeñaba el cargo de cónsul del Consulado de Burgos ${ }^{70}$; en 1532, un Luis de Castro, establecido en Londres, en union de otros mercaderes españoles, entre ellos, Álvaro de Astudillo, obtenía de Enrique VIII licencia de importación de 1691/2 toneladas de pastel de Tolosa ${ }^{71}$.

Entre los mercaderes residentes en Brujas, en 1514, se encontraban dos hermanos Castro: Fernando y. Juan. Éstos mismos, o sus homónimos de la siguiente generación, actuaban aún en tiempo de Íñigo: un Juan de Castro, mercader de Amberes y un Fernando de Castro designado, en un documento, como cuñado de Gonzalo de Aguilera por su mujer Ana de Castro ${ }^{72}$.

\section{b. Los otros linajes: Astudillo, Garay, Maluenda, Salinas}

El giro dado en la conducta del bachiller Juan de Castro y la reaccín de sus coterráneos aún tenían eco en Burgos, en 1542, catorce años después de la salida de Íningo de París y fundada ya la Compañía de Jesús en Roma. Ignacio mencionaba a cuatro familias burgalesas cuyos vástagos había conocido en aquella Universidad: Garay, Salinas, Maluenda y Astudillo. Le preocupaba que todavía, en esas fechas, corriera entre «estos linajes o casades» y otras familias que habían tenido hijos o parientes en París, noticias siniestras a su respecto, achacándole el proceder de Castro que juzgaban deshonroso y sospechoso. Entre los que así pensaban, se contaban el padre y el hermano de Juan Alfonso de Polanco, admitido por Ignacio, el año anterior, 1541, en la recién

\footnotetext{
68 BASAS 158-159. Juan de Castro participaba activamente en el mercado lanero de 1481 a 1511 CASADO ALONSO 208

69 MOLLAT 237518.519

70 BASAS Apéndice I 267

71 JAMES GAIRDNER Letters and Papers of the Reign of Henry VII vol. 5/2, 1532, London 1880, n. ${ }^{\circ} 1065,23$. Se les concedio la licencia el 11 mayo 1532, no obstante la prohibición existente, ya que tenfan el cargamento en el Támesis en virtud de ofra licencia anterior al nuevo estatuto (24 Henry VII). Los beneficiarios eran: «John Hordana (Jordana), Bernard de Bardignyer, Lives [sic] de Castro, and Albert [sic] de Astodiflo, merchants of Spain». El 2 de enero de 1532, «Alvarus de Astodillo, a Spaniard living in London había obtenido la naturalización. Ibidem n. ${ }^{\circ} 766,3$

72 GuILLIODTS Cantulaire 1, 229
}

Hispania, del Mediterráneo al Atlántico

Hispania Sacra 51 (1999) 
fundada Compañía de Jesús, actitud que ocasionaba un grave perjuicio tanto al nuevo miembro como a la nueva orden ${ }^{73}$.

Miembros de estos linajes que habían coincidido con Ínigo en París eran el Dr. Pedro de Garay, del colegio sorbónico; los Salinas Alfonso, Jerónimo (rector en 1530), Bernardino (rector en 1546) -tío carnal de Juan A. de Polanco-y Juan Alfonso; el Dr. Pedro de Maluenda, futuro teólogo del Emperador y el Dr. Francisco de Astudillo, profesor de Humanidades y Artes en el colegio de Mans ${ }^{74}$, bajo cuya regencia, Juan Alfonso de Polanco inició, en 1538, su magisterio en Artes $^{75}$.

Por estos años, entre los burgaleses con negocios en Brujas, Amberes, Londres y Ruán, había miembros de estas estirpes. En 1531, como aseguradores de un navío para un viaje de Lübeck a Arnemuyden se mencionan Álvaro de Maluenda, Martín de Salinas y Johan de Castro, mercaderes de Amberes ${ }^{76}$. En Brujas, estaban establecidos, en 1531, Álvaro de Castro y Álvaro de Maluenda, éste último, cónsul de España en enero de este año, que teñ́a también, como acabo de apuntar, negocios en Amberes ${ }^{77}$. En 1532, Luis de Castro y Álvaro de Astudillo negociaban en Londres, como se ha visto ${ }^{78}$.

${ }^{3}$ Ignacio a Araoz. Roma, 20 febrexo 1542. MHSI EppIgn L, 191. Esta era la advertencia de Ignacio: «Maestro Juan Polanco tiene en Burgos padre y madre, el padre llamado Gregorio de Polanco, regidor de la ciudad, y va hermano, que tiene entre otros; llamado asimismo Gregorio de Polanco, los quales padre y hermano están muy mal ynformados, y mucho desedificados de mí, y consequenter de la Companfía, á tanto que escriue al maestro Polanco cosas de lástima á él, porque á nosotros se allega, y de nosotros, no de pecados actua[191]les circa bonos mores, mas pintandonos como les plaçe, y entre otras cosas siento que, al juicio dellos, el mismo Polanco no sería seguro de la inquisiçión, lleuando nuestra conbersación y dotrina ... Si por bentura vbiésedes de yr á Burgos, tened en memoria que todos aquellos que an tenido sus hijos 6 parientes, 6 a lo menos vt in plurimum, en París, que estarán desedificados de mí, porque quando maestre Joán de Castro, bachiller en theología, que después se hizo dotor, era burgalés, andubo pidiendo por Dios por las calles de París, auiendo distribuido lo que tenía en pobres; y como en sumo grado todos sus coterráneos se resentiesen, todo se atribuía á mí; el qual se hizo después fraile cartuxo. Los tales que entonces yo conoçfa en Paris, eran Garai, Sallinas, Maluenda, Astudillo; por tanto, de todos estos linages 6 casades terneys adbertencia: pareciome vien auisaros en el Señor nuestro. Mas para poner en ello medio alguno, no os mouáis por lo que escriuo, mirando siempre mayor seruicio de Dios N. S.t.

74 G. VILLOSLADA La Universidad de Pan's 379-386. LARRAÑAGA 328-330

75 SCHURHAMMER Javier I, 309. En el Archivum Romanum Societatis lesu (ARSI) se conserva la correspondencia de Astudillo con Ignacio, ya General de la Compañía de Jesús, y con Polanco, publicadas en Monumenta Historica S.I.

76 GorIs 181 nota 2

77 GLLLODTS Cantulaire 1, 196287

78 GAIRDNER vol. $5 / 2$ n. ${ }^{\circ} 766,3 ; n . .^{\circ} 1065,23$ 
Sin embargo, una rama de los Salinas, establecida de antiguo en Brujas, era de origen vascongado (probablemente de Salinas de Añana, en tierra de Álava) $\mathrm{y}$ algunos de sus miembros fueron cónsules de la nación de Vizcaya ${ }^{79}$.

Para conocer la procedencia de los linajes que coincideron con Íñigo en Paría, hay que tener en cuenta que las listas proporcionadas por el P. Ricardo García Villoslada indican la díocesis, no la región, por tanto habría aún que precisar el origen. La diócesis de Burgos inclúa las Encartaciones, la de Calahorra se extendía a Vizcaya, la de Pamplona incluía Guipúzcoa. Por lo que varios «burgaleses» con apellidos vascongados podrían ser vizcainos, como Pedro de Arriaga (iur. 1532), Diego Lope de Arriaga (iur. 1535), Juan de Mendoza (iur. 1520-21), Fr. Juan Hortois [iOrtiz?] de Oribe (iur. 1526), etc. De la importancia e influjo de estos linajes y su poder económico, es muestra el sucederse sus miembros en el desempeño de los cargos de prior y cónsules del Consulado de Burgos $^{80}$, así como su participación en los asientos con la Corona: en marzo 1535, Juan de Castro, de Londres, con otros mercaderes burgaleses, entre ellos, Juan de Astudillo, entraron en la capitulación de un asiento de 120.000 ducados pagaderos a la reina gobernadora, María de Hungría, mediante giros sobre Amberes ${ }^{81}$. Antes habían suscrito asientos con el emperador, dos Castro: Jerónimo en 1523 y Juan (¿el de Londres?) en $1526^{82}$.

\section{Brujas y Amberes}

\section{a. Gonzalo de Aguilera}

El entonces joven burgalés Gonzalo de Aguilera sería años adelante uno de los principales mercaderes y armadores de Brujas. En compañía de su mujer, Ana de Castro, hija de Alonso, habitaba por ese tiempo, según tradición, el Hôtel den Pynappel, de su propiedad, en la calle Langhe Winkle (Cuadra larga)

${ }^{79}$ En 1504, dos Salinas, Cristóbal y Martín, eran, junto con Fernando de Orozco, cónsules de la nación de Vizcaya. Cristóbal lo fue de nuevo en 1512 y 1533 ECHEGARAY 93, 144-145

${ }^{80}$ Además de los Castro de Londres, Diego y Juan (cónsul el primero en 1498-1499 y prior el segundo en 1547-1548) y el otro (?) Juan de Castro, cónsul en 1524-1525, citados en el texto, ciñéndome grosso modo a la época de frigigo en París y Roma, encontramos un Luis de Castro (¿el de Londres?) dos veces cónsul (1546-1547 y 1550-1551). De los Astudillo, Lesmes fue cónsul en 15321533 y Nicolás en 1547-1548, 1551-1552 y 1555-1556. Los Maluenda desempeñaron el consulado: Luis en 1535-1536 y Álvaro (¿el de Londres?) en 1544-1545 y en 1548-1549. Francisco fue consul en 1546-1547 y en 1549-1550 y prior en 1553-1554. De los Salinas, fueron priores Martín en 1535-1536, Lope en 1537-1538 y Martín Alonso (¿el mismo Martín citado?) en 1548-1549. BaSAS Apéndice I 267-268.

81 CARANDE 3, 174

82 CARANDE 3,128130

Hispania, del Mediterráneo al Atlántico Hispania Sacra 51 (1999) 
llamada, luego, hacia 1580, Spanjaardstraat o calle de los españoles (en la feligresía de Sint-Gilliskerk) donde tenían su mansión los mercaderes castellanos. La casa de Aguilera hacía esquina con Kipstraat (calle del Gallo) y la manzana de la que formaba parte estaba flanqueada, al otro extremo, por la Korte Winkle (Cuadra corta) y cerrando por detrás, la Vlamingstraat, o calle de los flamencos donde también habitaban mercaderes españoles. En la Lange Winkel se encontraba el consulado de España con la lonja y la Weech-huus, o casa pública de pesos y medidas. La calle, aun hoy día, desemboca en el Augustijnen Brug, o puente de los Agustinos, de donde arranca Spaanje Loskaai o muelle de España sobre uno de los canales del Zwin. Muy cerca, estaba el consulado de Vizcaya en Biskajersplein, o plaza de los Vizcainos ${ }^{83}$.

En mutua correspondencia, Aguilera, en sus viajes de negocios a París, se hospedará con Íñigo en su misma habitación ${ }^{84}$. Años adelante, en 1570, ayudó a la fundación de la Compañía de Jesús en Brujas. Muy longevo, murió en esta ciudad el 10 noviembre 1595 y se enterró, junto a su mujer en SintAugustijnskerk, la Iglesia de la nación española ${ }^{85}$.

Íñigo pudo ver los progresos de Brujas: en 1530, se construyó la fachada en piedra tallada del consulado de Castilla y el 27 agosto de este mismo año, Silvestre Pardo y su mujer Josine, hija del difunto Juan López [Jehan Loupes], fundaban el convento de la Anunciada.

En la primera visita a Flandes, durante la Cuaresma de 1529, Íñigo fue comensal del antiguo profesor del colegio de Monteagudo, el conocido humanista Juan Luis Vives, vecino de la misma calle Lange Winkel a pocos metros de Aguilera. De la conversación de sobremesa da noticia el burgalés Juan Alfonso de Polanco, según información de su coterráneo el Dr. Pedró de Maluenda, discípulo de Vives en Lovaina y conocido de Î́nigo en París ${ }^{86}$. De no haber sabido el informador el hecho, de modo directo, o incluso haberlo presenciado, la noticia le pudo haber llegado por uno de la familia, Álvaro de Maluenda, residente en Brujas ${ }^{87}$. Vives mantenía buenas relaciones con los mercaderes castellanos que lo tomaban por árbitro de sus litigios. En 17 enero 1531, por ejemplo, pronunciaba una sentencia arbitral entre varios, de los que uno era el mismo Ålvaro de Maluenda, a la sazón cónsul de la «nación de Burgos» ${ }^{88}$.

\footnotetext{
83 E. REMBRY Saint Ignace de Loyola d Bruges. Bruges 1898, 10, nota 2, 22-24. MARÉCHAL 32-34

${ }^{84}$ Acta SS. lulii VI, 439

85 REMBRY 10 nota 2, 32-35. El epitafio señala a Ana como "Alphonsi filia»

86 PoLANCo Vita, cap. VI, n. ${ }^{\circ}$ 55. MHSI Fontes narr. II, 557. Véase G. VILloslada Nueva biografía 312-316, con bibliografía sobre el encuentro.

${ }^{87}$ GuLliodTs Cantulaire 1, 287

88 GULLIODTS Cantulaire 2, 618
} 


\section{b. Juan de Cuéllar}

Juan de Cuéllar, nacido en Segovia en 1507, hijo de Diego Cuéllar y Francisca de Riaza, emigró a Flandes muy joven. Su padre tenía negocios en Nantes y la familia se establecí pronto en Brujas donde, en 1531, había un Luis de Cuéllar. En Saint-Omer, Juan contrajo matrimonio con la flamenca Clara Pels y se instaló en Amberes en 1531, donde llegó a ser uno de los mercaderes extranjeros más opulentos de la ciudad; nunca regresará a Castilla ni a España. Murio en 1583, dejando cuatro hijos: Bernardo, Antonio, Francisca y Clara ${ }^{89}$. La casa habitada por Cuéllar, la llamada Den Roozenkrans, donde, según la antigua tradición, aloj6 a f́nigo, se encontraba frente al portal del costado sur de la iglesia de Santiago (Sint-Jacobskerk), en la calle Larga Nueva (De Lange Nieuwstraat), esquina a Eikenstraat (o del Roble). Su posterior propietario, después de la canonización de Ignacio de Loyola (1622), colocó en la casa una placa conmemorativa de su estancia en ella y paś a conocerse por Sint Ignatius ${ }^{\circ 0}$.

\section{c. Pedro Cuadrado}

En Amberes, había también conocido a Íñigo, Pedro Cuadrado, joven mercader natural de Medina del Campo, alojado en casa de Cuéllar. Según su propio testimonio, algunas veces había convidado a Ínigo a su mesa y le había dado limosna. Recordaba que Íniigo le había tratado con especial predilección, al menos así le parecía. Años adelante, en 1557, fundó con su mujer, Francisca Manjón, el colegio de la Compañía de Medina del Campo. El mercader medinés consideraba un premio de Ignacio a sus limosnas el haber podido ser «fundador de vn su collegio' ${ }^{91}$.

89 RAFAEL RÓDENAS VILAR Vida cotidiana y negocio en la Segovia del Siglo de Oro. El mercader Juan de Cuéllar. Junta de Castilla y León, Valladolid 1990. p. 66 . El personaje protagonista de esta obra es distinto del de Amberes, aunque pariente. Para su homónimo de Amberes, protector de fnigo, véase GORIS pp. 249 307/308 411612 627. V. VAZQUEZ DE PRADA Lettres marchandes d Anvers 4 vol. Paris 1960. 1, 217-218. RÓDENAS llama a la esposa de Cuéllar Catalina, en vez de Clara. Pero véase A. PONCELET, S.I. Histoire de la Compagnie de Jésus dans les anciens Pays-Bas. Etablissement de la Compagnie de Jesus en Belgique et ses développements jusqu'à la fin du règne d'Albert et d'Isabelle [1542-1633]. I. Histoire générale (Bnuxelles 1927) 34-39. El nombre de Clara consta también en un documento de 23 abtil 1582. GuLlIODTS Cartulaire 515 y PRADA 217.

90 PONCELLET I 34-39. LARRAÑAGA 316-321, notas 13-15. Agradezco al P. Joseph Vercruysse, S.J., Profesor de Historia Eclesiástica en la Facultad de Teología de la Pontificia Universidad Gregoriana, su ayuda en la transcripción de términos neerlandeses, así como a los Srs. J. Icks y L. Winckelmans sus sugerencias. En 1991, se colocó una placa conmemorativa, en neerlandés, sobre el muro izquierdo de la calleja que conduce al portal sur de Sint-Jacobskerk y aún se conservaba en 1996.

91 P. DE GUZMAN «Colegio de Medina del Campo» en «Historia de los Collegios de Castilla» ARSI Cast 35/ f. 260v. LARRAÑAGA 319-320. Una deformación hagiográfica de este dicho (a partir

Hispania, del Mediterráneo al Atlántico

Hispania Sacra 51 (1999) 


\section{Las conexiones segovianas: caballeros y mercaderes}

El conocimiento de Íñigo de su huésped de Amberes, Juan de Cuéllar, podría haber sido no meramente casual, pues existe una tradición y unos presupuestos que unen a Íñigo con Segovia.

\section{a. Los Cáceres}

Según esta tradición, trasmitida por el P. Luis de Valdivia, Íñigo se habría hospedado en las casas de un tal «Don Gonzalo de Cayres, cauallero principal». Todavía, hacia 1630, se veneraba y señalaba el aposento donde le hospedó este caballero ${ }^{92}$. Al no figurar el apellido Cayres en los registros segovianos, se trataba, sin duda, de Don Gonzalo de Cáceres que, con otros miembros de la familia, tomó partido por las Comunidades en $1521^{93}$. Una lectura errónea de este apellido, quizás en su forma sincopada Caçres, habría dado «Cayres ${ }^{94}$. La mansión sería la de los Ossorio de Cáceres, en el barrio de los Ca-

de Maffei) que recogen también los Bolandistas, supone que fínigo, en agradecimiento a su limosna, profetizó a Cuadrado que sería fundador de un colegio de la futura Compañía, lo cual no corresponde al proceso que llevó a Ignacio y a sus compañeros a fundar una Orden religiosa, en 1540, y, en ella, a la aceptación de colegios algunos años después. Ribadeneyra no hace la menor alusión a la supuesta profecía y refiere simplemente que, a Cuadrado, le parecía «que Dios nuestro Sefior se había querido servir de su hacienda, y héchole aquella merced [fundar el colegio] por las oraciones de nuestro Beato Padre y por la comunicación que había tenido con su santa persona» Vida del Padre Maestro Diego Lainez II, 3. PEDRo DE RIBADENEYRa Historias de la Contrarreforma. Introducción y notas por EUSEBIO REY. Madrid 1945 (=BAC 5) p. 502

92 LUIS DE VALDIVIA «Collegios de la Provincia de Castilla», cap. 7 «Collegio de Segovia» (ms. en la biblioteca del Institutum Historicum Societatis Iesu [IHSI], Roma). J.I. GARCIA VELASCO (ed.) San Ignacio de Loyola y la Provincia jesultica de Castilla. León 1991, cap 7. Segovia p. 213, nota 1, supone, sin citar fuentes, que la estancia tuvo lugar cuando finigo servía en la corte.

${ }^{93}$ Historia crítica y documental de las Comunidades de Castilla. 6 vol. Memorial Histórico Español (XXXV-XI). Madrid 1897-1900. De los Cáceres, Diego fue enviado con instrucciones por la ciudad de Segovia a la Santa Junta y encargado de hacer el alarde de la gente: 1, 453-454; Fernando, acompaño a la Junta a Medina, como capitán: 2, 739-740. Un Gonzalo de Cáceres, con casas en Madrid, figura en el «Memorial de los exceptuados [del perdón general] y desterrados de Madríd». Su hacienda, destinada a venderse, en castigo, valía más de 800 ducados. Ibidem 5, 287314 . DIEGO DE COLMenares Historia de Segovia. Segovia 1921. III, 50 60. Antes, en las luchas banderizas que siguieron a la muerte de Felipe el Hermoso, los Cáceres tomaron el partido de los marqueses de Moya. Bbidem 15

${ }^{44}$ El mss. de Valdivia y los autores que le siguen escriben claramente «Cayres», pero, según información del profesor García Sanz, que agradezco, este apellido no figura entre los regidores segovianos de 1504-1505, ni en la lista de más de 100 nombres de «mercaderes» de Segovia entre 15051510 , ni en el vecindario de Segovia de 1561, ni en ninguno de los muchos documentos segovianos consultados. Apunta el profesor que se podría tratar de Gonzalo de Cáceres, en lo que estoy de acuerdo, pues se puede suponer, con fundamento. una compción de transcripción de un original «Caçres», 
balleros, casa fortificada, protegida por una torre almenada con troneras, que defendía las murallas de la ciudad a propósito para alojamiento de personajes de la corte a los que Ínigo acompañaba. Alquilada para sede de la Inquisición de 1480 a 1494, se devolvió en este año al mayorazgo Francisco de Cáceres ${ }^{95}$.

La relación de Íñigo con Segovia y con Gonzalo de Cáceres explicaría mejor el hecho de que uno de los compañeros de primera hora que se le unieron en Barcelona, entre 1524-1526, fuera el segoviano Lope de Cáceres que estaba al servicio del virrey de Cataluña. Polanco, que aporta el dato, omite el nombre del virrey, pero se trataba sin duda de D. Fadrique de Portugal que sucedió en el virreinato a D. Antonio de Zúñiga, en 1525. A la sazón obispo de Sigüenza y, a partir de 1532, arzobispo de Zaragoza, Don Fadrique había ocupado la sede de Segovia de 1508 a 1511. Anteriormente, obispo de Calahorra (15031508), había sido uno de los firmantes del testamento de Isabel la Católica ${ }^{96}$. Pertenecía a una rama bastarda de los reyes de Portugal y había servido en la corte de los Reyes Católicos. Dentro de la jurisdicción calagurritana se encontraban los estados del duque de Nájera, emparentado con los Loyola. Ambas circunstancias hacen pensar en la posibilidad de un conocimiento previo, por parte de f́ñigo, del virrey y de miembros de su séquito.

Un segundo Cáceres segoviano, Diego, estudiante de la Universidad de París (iuratus en 1534), se mostró afecto a fñigo y formó parte del grupo de compañeros parisienses hasta poco después de su ordenación sacerdotal, en 1541 6 1542. En Roma, participó, en 1539, en las deliberaciones de los primeros padres para la fundación de la Compañía de Jesús, cuyos documentos firma junto con ellos, pero, según los autores, no llegó a pertenecer a la Compañía fundada en 1540. Luego fue espía al servicio de Francisco I y, luego, del rey de Navarra Enrique de Albret $^{97}$.

con lectura de «ç» como «y», La forma «Caçres» ocurre en los procesos de Alcalá de 19 nov. 1526 contra Ínigo de Loyola (MHSI Scripta de Sancto Ignatio de Loyola Societatis lesu fundatoris. I. (Madrid 1904) 325602 y en las «Deliberaciones» de 1539 en Roma MHSI, Sancti Ignatii de Loyola Constitutiones Societatis lesu. I. Monumenta Constitutionum praevia Rona 1934, XLV-XIVI.

95 COLMENARES II, 345-346. La cédula de devolución la conservaba su cuarto nieto, Gonzalo de Cáceres. A fines del siglo XVI vivían, en Segovia, dos Gonzalo de Cáceres, padre e hijo. Ibidem III, 251. Para la casa de los Cáceres, que, luego, pasó a los marqueses de Lozoya, véase José Marf́a AVRIAL Y FLORES Segovia pintoresca y el Alcázar de Segovia. Texto y láminas con estudios preliminares del Marqués de Lozoya y D. Eltas Tormo. Segovia 1953. Instituto Diego Velázquez (CSIC) pp. 40-41 (16m. 5)

96 POLANCO Sumario cap. 2 n. 35. MHSI Fontes narr. I, 170-171. Durante los dos años de estancia de f́ffigo en Barcelona (1524-1526) hubo relevo de virreyes. JOAN REGLA Els Virreis de Catalunya. Barcelona 1956, 93. Diccionario de Historia Eclesiastica de Espafia. 4 vol. Madrid 1972-1975. I, 212; IV, 24002476

97 G. VILLOSLADA La Universidad de Parts 395, aparece como Diego Cárceres [sic], sin duda corrupción de Cáceres. SCHURHAMMER Javier I, 311 nota 141.

Hispania, del Mediterráneo al Atlántico

Hispania Sacra 51 (1999) 
Otro de los compañeros de Barcelona, Calixto de Saa, estaba también relacionado con Segovia y era muy probable que fuera conocido de Cáceres y que perteneciera igualmente al séquito de Don Fadrique.

En unión del tercer compañero de Barcelona, el estepeño Juan de Arteaga y Avendaño, Lope de Cáceres y Calixto de Saa siguieron a Íñigo a Alcalá y a Salamanca. Una vez que f́̃̃igo marchó a París, en 1527, quedaron a la espera de reunirse con él en la villa del Sena. Íñigo mantuvo comercio epistolar con ellos, pero, por entonces, no encontro facilidad de alojamiento ni medios de subsistencia convenientes y cada uno siguió su propio camino. Lope de Cáceres volvió a Segovia donde «comenzó a vivir de tal modo que parecía haberse olvidado del primer propósitom 98 .

\section{b. Calixto de Saa y los Cuéllar}

En 1526, durante sus estudios en la Universidad de Alcalá, ínigo estuvo en Segovia atendiendo a Calixto de Saa, gravemente enfermo ${ }^{99}$. Algunos autores, basados en esta circunstancia, suponen a Calixto segoviano. Sin embargo, su apellido y la recomendación de Ínigo a Leonor de Mascarenhas (dama de la difunta emperatriz Isabel y aya de su hijo, el Príncipe Felipe) con el fin de obtenerle una de las 50 becas dotadas por Juan III de Portugal para los estudiantes de esta nación en el colegio de Santa Bárbara, así como su envío, por doña Leonor, a la corte de Lisboa con cartas de recomendación, una mula y dinero para gastos, indican claramente su origen portugués. De todos modos, su presencia en Segovia y su posterior ida a Nueva España como mercader, de la que regresó rico, maravillando en Salamanca a los que le habían conocido, pudiera indicar su pertenencia a una familia de mercaderes portugueses afincados en Segovia, o simplemente una relación con la ciudad nacida durante el pontificado de Don Fadrique, en cuyo entomo se hubiera movido ${ }^{100}$.

\footnotetext{
98 Autobiografia cap. VIII, $\mathrm{n} .{ }^{\circ} 80$

99 POLANCO Sumario cap. 2, n. 37 . MHSI Fontes narr. I, 173-174

100 Autobiografía cap. VIII, nn. 79-80, nota 16. LARRAN̂AAGA 340-345, notas 32-35. El conocimiento de Leonor de Mascarenhas, con la que f́nigo mantendrá correspondencia hasta el fin de su vida, databa de 1527. Según Ribadeneyra, doña Leonor, en unión de Teresa Enríquez (la $\ll$ Loca del Sacramentow), madre del duque de Maqueda, le ofreció sacarlo de la cárcel de Alcalá, lo que fíigo rehusó por confiar en su verdad e inocencia y por su deseo de padecer por Cristo (RIBADENEIRA Vita Ignatii Loyolae. Textus latinus et hispanus cum censuris. Edidit CANDIDUS DE DALMASES. Romaz 1965 (en adelante RIBADENEYRA Vita), lib. I, cap XIV, n. ${ }^{\circ} 67$. MHSI Fontes narr. IV, 182). Ínigo podría haber visto, de nuevo, a donia Leonor, a fines de junio: dictada la sentencia (1 de junio), fue a Valladolid para informar al arzobispo de Toledo, Alonso de Fonseca, de lo actuado por su vicario Juan Rodríguez de Figueroa y poner su causa en sus manos. El arzobispo se encontraba, con la corte, en Valladolid en ocasión del bautizo del príncipe Felipe ( 5 junio). En ese tiempo se reunió alll la junta
} 
En este contexto segoviano, Íñigo habría podido conocer de antaño a los Cuéllar o a personas relacionadas con ellos. Dado su origen plebeyo no parece que este linaje estuviera emparentado con el contador Juan Velázquez de Cuéllar, aunque nada se puede afirmar en favor ni en contra, ni obstaría el posible origen neocristiano de los Cuéllar segovianos para que no se diera, cuando menos, un parentesco lejano ${ }^{101}$. Pero, aunque no existiera tal parentesco, la presencia de f́ñigo de Loyola en Segovia en diferentes ocasiones - con la corte o sin ella - le pudo haber puesto en relación con sus caballeros y mercaderes.

\section{Londres}

El viaje a Londres y el hospedaje no habría ofrecido mayor dificultad. Los castellanos frecuentaban, de antiguo, los principales puertos del sur de Inglaterra, pero Londres era, en términos absolutos, el centro más importante del comercio anglo-castellano. El trato de Londres con Brujas y Amberes, entorpecido en los años de la guerra, se había normalizado en 1529 y los paños ingleses volvieron a las ferias flamencas y brabanzonas. La travesía de Londres a Amberes no empleaba mucho tiempo: en un queche podía hacerse en día y medio ${ }^{102}$.

En Londres, Iñigo pudo haberse hospedado en St Katharine's Hospital, junto a la Torre, en el distrito donde se alojaban los mercaderes españoles, agrupados, sobre todo, en torno a Tower Street y a ambos lados de Tower Hill $^{103}$. En la ciudad del Támesis, estaban establecidos, entre otros, los Castro y los Astudillo y los factores de burgaleses de Brujas, como los Salinas o los

de teólogos convocada por el cardenal arzobispo de Sevilla Alonso Manrique de Lara, Inquisidor General, para el examen de las proposiciones erasmistas (27 junio-13 agosto). cf. VLloSLADA Nueva biografia 291-294.

IOl RÓdENAS VILAR 65-74. Para la nobleza del Contador cfr. BaLbino Vel.asco Bayón Historia de Cuellar. Diputación Provincial (Segovia ${ }^{2} 1981$ ) $242-243$ y JESÚS LARIOS MARTIN Nobiliario segoviano. Instituto Diego de Colmenares. vol. V (Segovia 1967), 148-149. No se excluiria un parentesco. Así lo cree el erudito historiador de la juventud de înigo, P. Luis Fernández Martín, según me comunica.

102 El correo de la reina Catalina de Aragón, Montoya, enviado a Roma, vía Flandes, empleó día y medio en llegar de Londres a Amberes. Chronicle of King Henry VIII of England ... written in Spanish by an unknown author (Translated, with notes and introduction by MARTIN A. SHARP HUME) London $1889,5-6$.

103 Hume Chronicle xxii-xxiii. Algunos autores, orientados más bien hacia la espiritualidad, to suponen, unos, huésped de los cartujos y, otros, del monasterio de Syon, cerca de Isleworth y no lejos de Richmond a unas dos horas de la City, por recomendación de Vives que lo habría relacionado incluso con la reina Catalina: WILLEM A.M. PETERS, S.J. Richard Whitford and St Ignatius' visit to London AHSI 25 (1956) 328-350. No se duda que, como en París, hubiera frecuentado la Cartuja y otros lugares de devoción, pero, dada su práctica en Flandes, parece más seguro lo que indico, que es la opinión más común entre los historiadores de lengua inglesa.

Hispania, del Mediterráneo al Atlántico Hispania Sacra 51 (1999) 
Maluenda ${ }^{104}$, linajes todos de compañeros de f́ñigo en París. Es, pues, muy verosímil que le recibieran en su casa, al igual que en Brujas y Amberes, alguno de estos mercaderes quizás uno de los Castro ${ }^{105}$.

\section{Ruán y las plazas de contratación francesas}

Como se ha señalado, Íñigo solía ir también a la plaza normanda de Ruán y a otras plazas de contratación francesas a donde acudían los mercaderes españoles para sus tratos ${ }^{106}$. Fundado en un pasaje de la Autobiografia (cap. VIII, n. ${ }^{\circ}$ 79), Michel Mollat supone que Íñigo tenía conocimiento con mercaderes, armadores y maestres de naos de Ruán. Cita el caso de su camarada español de París malversador de sus escudos que, por el verano de 1529, enfermó en Ruán mientras esperaba embarcación para España. İ́nigo fue a visitarlo desde París y, gracias a sus amistades ruanesas, le consiguí pasaje gratuito en una embarcación mercante ${ }^{10}$.

$\mathrm{El}$ argumento no es del todo concluyente, ya que la frase del original italiano «lo aiutò a metterlo in nave per andar in Spagna» puede significar una simple ayuda económica para el pago de su pasaje. En este caso, le bastaba a Ínigo gastar parte del dinero recién traído de Flandes aquella Cuaresma, o ejercer la mendicidad a su viejo estilo. Sin embargo, al ocurrir el hecho después de su primer viaje a Flandes, pocos meses atrás, no es tan inverosímil esta amistad, o mejor conocimiento, dadas las relaciones familiares y comerciales entre los mercaderes españoles de Flandes y Ruán, p.ej., los Maluenda ${ }^{108}$. Siguiendo a Araoz, tampoco sería inverosímil que Íníigo, en este primer viaje a Flandes, hubiera tocado en Ruán.

Por otra parte, Mollat basado en Dudon, funda su interpretación en las presuntas buenas relaciones con ínigo del Principal del colegio de Santa Bárbara, Diogo de Gouvea quien le habría recomendado a mercaderes ruaneses. Pero esta conjetura no parece tan probable ya que Gouvea estuvo ausente de París, por comisión de Juan III, de septiembre de 1528 a junio de $1529^{109}$ y el viaje

\footnotetext{
104 CHILDS 215-216, 224-225. CASAdo Alonso 200.

105 PAUL DUDON Saint Ignace de Loyola, Paris 1934, 179-180. Este autor admite la posibilidad de que fuera Luis Vives quien le recomendara a sus amistades de Londres, Ibidem 182. 207.

106 Quadam de P. Ignatio qua non sunt impressa (ca. 1582), nn. [5]-[6]. MHSI Fontes narr. III,

I07 MOLlat 517 540. Esta es la frase aludida en la Autobiografía (cap. VII n. ${ }^{\circ}$ 9); «In Ruano consolo lo infermo e lo aiuto a metterlo in nave per andar in Spagna; et gli dette lettere indirizzandolo alli compagni che erano in Salamanca, cioe Calisto et Caceres et Artiagas.

108 MOLLAT 192-193 n. 72, 243 515-519. DUDON 203-304.

109 SCHURHAMMER Javier 1, 129 n. 205.
}

Hispania, del Mediteráneo al Atlántico Hispania Sacra 51 (1999) 
de ínigo a Ruán se realizó el verano de este último año, cuando el cambio operado en Amador de Elduayen decidió a Gouvea darle una sala a ínigo «por seductor de los escolares», la primera vez que apareciera por el colegio. A la postre, el humillante castigo no tuvo lugar y fue el principio de esas buenas relaciones de Gouvea con Înigo y sus compañeros ${ }^{110}$. Recibido Íñigo en Santa Bárbara, como colegial, para el $10^{\circ}$ de octubre 1529, Gouvea se ausentó, de nuevo, de noviembre de 1529 a septiembre de 1531. Para esta última fecha, Íñigo había entablado estrechas relaciones con sus bienhechores y no iba a tener necesidad de efectuar nuevos viajes a las plazas de contratación de la Europa norteña.

La presencia de Diogo de Gouvea en Ruán estaba relacionada con el mercado de la Especiería en el que se integraban grupos de extranjeros muy activos desde el comienzo del siglo XVI, entre los que se distinguían cuatro o cinco familias burgalesas con base en Lisboa y Amberes, a donde, en 1499, se había trasladado, desde Brujas, el factor real portugués. Entre los más activos y poderosos en el comercio de la especias, se encontraban dos Castro burgaleses, Juan, mercader, morador de Lisboa en 1500, en buenas relaciones con el rey portugués, y Pero, comprador de especias en la Casa da India en 1509-1511 (pimienta) y 1522 (jengibre). También participaban los Maluenda, dinastía ascendente ramificada por varias naciones de Europa con una red de negocios que se extendía de Burgos a Ruán, Lisboa y Amberes en torno al eje de Medina del Campo - Amberes ${ }^{111}$.

En Nantes, se habían establecido mercaderes de Bilbao - para la contratación entre ambos puertos y Brujas-y también burgaleses, como los Astudillo, Bernardo y Fernando ${ }^{112}$.

Los linajes burgaleses, mencionados por fñigo o por sus bígrafos, que operaban en la Europa septentrional, no agotan todas las otras redes familiares de mercaderes que Î́igo pudo conocer en la Universidad de París o recibir su ayuda en Flandes. Por ejemplo, linajes emparentados con los Aguilera, como los Camargo, los Lerma o los López, o asociados con ellos, como los Covarrubias, los Salamanca (Garcias de Salamanca iur. 1532), los Pardo, los Carrión

110 Autobiografía nn. 77-78. Habría quizás una remota posibilidad de un conocimiento previo de Iñigo y Gouvea con motivo de la presencia de ambos en Valladolid en el verano de 1528 y la relación de ínigo con Leonor de Mascarenhas, pero habria que probar la coincidencia de fechas. Diogo de Gouvea, a su paso por Valladolid, en su viaje de Portugal a Francia, fue invitado a participar en la junta de té́logos (27 junio-13 agosto) que mencionamos en nota 100. cf. BRANDAO A Inqquisição L, 84-88.

11 V. MAGALHĀES GODINHO Os Descobrimentos III 183-214 Lisboa ${ }^{2} 1987,190-203-205$. A. A. MARQUES DE ALMEIDA Capitais e capitalistas no comércio da Especiaria. O eixo Lisboa-Antwerpia (1501-1549). Aproximaçāo a un Estudo de Geofinança. Lisboa 1993, 23-24 62-65.

112 MATHOREZ 14 (1912) 387; MOLLAT 518-519 y n. 306. Fernando Astudillo se naturaliza en junio 1532.

Hispania, del Mediterráneo al Atlántico Hispania Sacra 51 (1999) 
(Gregorio Carrión, iur. 1533-34) o Diego de Mazuelo (iur. 1522) cuyo homónimo era banquero en Burgos. Sin contar linajes navarros, como los Lumbier: Juan de Lumbier era compañero de Íñigo en París (iur. 1530) y Michiel, mercader de Amberes y uno de los firmantes de la solicitud de fundación del consulado de Navarra en Brujas, negociaba, en Ruán, por conducto de Martín de Maluenda ${ }^{113}$.

De todo lo dicho se puede inferir, con fundamento, que Íñigo sabía a quiénes dirigirse en las plazas mercantiles del norte de Europa, mucho más si, como algunos apuntan (p. ej., REMBRY) -y pienso que con razón-- el burgalés Juan de Castro era pariente cercano de Ana de Castro, mujer de Gonzalo de Aguilera. La familiaridad de éste con Íñigo hasta el punto de alojarse, en sus viajes a París, en la propia morada de Ínigo, lo confirmaría. Juan de Castro lo habría recomendado a Ana y a su marido en Brujas y el matrimonio Aguilera le habría facilitado la entrada con los otros mercaderes de la nación ${ }^{114}$.

\section{Vizcainos y catalanes}

La primacía del trato de Íñigo con los mercaderes castellanos, consecuencia de la importancia de éstos y de posibles conocimientos anteriores, en la corte o recientes en París, con familiares o socios de este grupo, no quiere decir que no tuviera relación con los otros grupos de españoles. Su origen guipuzcoano y la participación familiar en el circuito comercial del hierro y en el transporte marfímo, le podrían haber allanado el contacto con sus paisanos vascongados presentes en Flandes, los llamados de modo genérico vizcainos: mercaderes, armadores y maestres de naos.

Del mismo modo, su amistad con algodoneros (cotoners) de Manresa y Barcelona, como la familia Pasqual, y con damas de la aristocracia barcelonesa le habría dado acceso al grupo catalán o a sus agentes en París, sobre los que, sin duda, le giraban las letras de cambio. Íñigo mantuvo frecuente correspondencia con sus amistades de Barcelona, de la que nos han llegado noticias de cartas y socorros pecuniarios recibidos por medio de mercaderes a su llegada a París, o de personajes vinculados a la Universidad parisina, como posiblemente lo era el doctor Benet por cuya mano recibio Iñigo, por noviembre de 1532, cartas y una provisión de Barcelona ${ }^{115}$.

\footnotetext{
113 MOLLAT 192 nota 72

114 REMBRY 25-27

115 Ignacio a Isabel Roser. París, 10 noviembre 1532. MHSI Epplgn I, 83-89. No consta quién fuera este doctor. Quizás pudiera tratarse del anciano dominico aragonés Fray Cipriano Benet, profesor sorbónico, del convento de los Jacobitas de París frecuentado por finigo. Alín vivía en 1531. Profesor en París en los primeros afíos del siglo, había vivido en Roma donde publico parte de su obra, pero 


\section{LAS AYUDAS DE ESPAÑA: LOS GIROS DE BARCELONA}

En cuanto a su sustento personal, ínigo lo sufragaba con la provisión anual que sus amigas pudientes de Barcelona le enviaban regularmente a París, como lo harían más tarde a Venecia donde terminó sus estudios. Araoz menciona la ayuda de una «una señora de Barcelona». Aunque varias personas le asistían, Inés, o Agnès Pasqual, a quien fñigo consideraba como a una madre, era la que más se preocupaba de que le llegara la provision ${ }^{116}$.

Años adelante, Joan Sagristà Pasqual, hijo de Inés, testificaba que su madre enviaba a Íníigo, mientras estudió en París, una provisión anual de 100 ducados en letras de cambio para libros, gastos personales y lo que se le apeteciera («lo provehia ab cambis ma mare de cent ducats cada añy per a libres per a son gasto $i$ per a son gust»). Invocaba, para confirmarlo, el testimonio del Padre Maestro Fray Ramón Pasqual, O.P. (quizás su pariente), compañero de estudios de f́nigo en París durante cuatro o cinco años y residente entonces (1582) en el monasterio de Santa Catharina de Barcelona. La mayor parte de esta suma Íñigo la empleaba en limosnas y ayuđas pecuniarias a sus compañeros, a otros estudiantes escasos de recursos y a menesterosos en general ${ }^{117}$.

Recuérdese que 100 ducados era precisamente la cantidad que el mercader y regidor de Burgos, Gregorio de Polanco, asignaba a su hijo Juan Alfonso para sus estudios. Por consiguiente, f́nigo disponía de un caudal más que suficiente para sus estudios, semejante al del estudiante de un alto nivel económico. Otra cosa era su empleo que, como acabo de indicar, beneficiaba a sus compañeros más necesitados. La escasa documentación disponible no permite precisar si los 100 ducados procedían íntegros de Inés Pasqual o si ésta era la encargada de girarle el total recaudado entre las bienhechoras de Barcelona.

\footnotetext{
no consta ni la fecha ni el lugar de su muerte (G. VILLOSLADA La Universidad de Paris pp. 27 31, nota 9). Sea lo que fuere, el doctor conocido de Ignacio y de sus devotas, fallecí́ antes de junio 1533. Ignacio a Iness Pasqual. París, 13 junio 1533. MHSI EppIgn I, 90

116 Inigo, en carta a Inés Pasqual de junio 1533, tefiriendose a una carta suya del año anterior, recibida por mano del Dr. Benet junto con la limosna y provisión de Barcelona, le decía: «Por vuestra carta conoci, y por la información que aca me hizieron, la mucha diligencia, que en mis cosas pusistes, con voluntad muy entera, como siempre en mí mostrastes; asimismo para adelante os offreciades mucho para poner diligencia y sollicitud en ello: parece que, no sólo me teneis hechado en cargo por lo passado, mas aun por todo lo poruenir quereis que yo sea ligado. Plegue á Dios N. S., que aquel Seffor uerdadero, por cuyo amor y reuerencia lo hazeis, os lo paguew. Parrs, 13 junio 1533. MHSI Epplgn I, 90

i17 2..$^{\circ}$ testimonio de Joan Pasqual, n. ${ }^{\circ}$ [13]. Barcelona, 9 marzo 1582. MHSI Fontes narr. III, 195-196. Joan afirma de sl mismo que era «menestral harto rico», pero se empobrecio: en un affo tuvo una pérdida de más de 900 ducados. Primer testimonio de Joan Pasqual. Barcelona, 7 julio 1579. Ibidem 149
} 
Según los acontecimientos referidos, parece que Íñigo, después del desfalco sufrido, en 1528, por cuenta de su compañero, no quiso acudir inmediatamente a Barcelona en demanda de ayuda para recuperar lo perdido, sino que trató de vivir de limosna o como fámulo de algún maestro parisino que no pudo encontrar. Para comienzos del curso 1531-1532, el problema económico estaba suficientemente resuelto con los dineros recolectados en Flandes. En noviembre 1532, acusaba recibo a Isabel Roser de sus cartas y de 20 ducados enviados por medio del Dr. Benet. Agradecía a las otras hermanas en Cristo sus ofrecimientos, especialmente a Leonor Ferrer, mujer de Sever Çapila, que le había insistido en que le escribiera indicándole sus necesidades. Disculpaba las excusas de la Roser y de las otras bienhechoras de no poderle ayudar más debido a otras obligaciones, expresándoles su agradecimiento. Tenía suficiente para un año y esto le bastaba, pues no sabía lo que pasaría el año siguiente, por ello no le parecía conveniente escribir a la Çapila ni a las otras para el envío de la limosna ofrecida ${ }^{118}$.

Sin embargo, antes del año, tuvo que hacerlo con motivo de los gastos extraordinarios inexcusables ocasionados aquella Cuaresma por la obtención del grado de Licenciado en Artes (13 marzo 1533) ${ }^{119}$, que habrían podido elevarse a unas 56 libras tornesas, 13 sueldos $^{120}$, es decir, a unos 28 escudos del sol cantidad muy apreciable. Podría equivaler, al cambio, a unos 25 ducados, poco más o menos ${ }^{121}$.

Estas expensas extraordinarias incluían las gratificaciones reglamentarias a los bedeles y el banquete ofrecido a los compañeros y maestros examinadores, lo que habfa elevado el costo de sus estudios más de lo ordinario ${ }^{122}$, sobre todo en un año de alza de precios exorbitante. En junio, ́́ñigo acudió a la Capila aceptando su ofrecimiento del año anterior. A Inés Pasqual le comunicaba la obtención de su grado y su elevado costo: había gastado más de lo que pedía su «auctoridad y podía» y había «quedado muy alcansado». No escribía a las otras bienhechoras por no importunarlas. Inés podía, si lo creía oportuno, comunicarles su apuro, pero creía mejor no decir nada a Isabel Roser por no desazonarla, pues le había expuesto, poco antes, su imposibilidad de socorrerle.

\footnotetext{
118 Ignacio a Isabel Roser. París, 10 noviembre 1532. MHSI EppIgn I, 83-89

119 SCHURHAMMER Javier 1, 315. G. VILLOSLADA Nueva biografía 330. La Inceptio, o lección magistral, con la imposicion del birrete de Magister Artium, tuvo lugar en marzo de 1535. El diplona se le extendió el 14 marzo 1534 (cómputo galicano, esto es, 1535 antes de Pascua) $\mathrm{Ibidem}$

120 SCHURHAMMER Javier 1, 205

121 Hacia 1550, se cambiaba 1 ducado (375 maravedis) por 440 dineros torneses: Soro lib. VL, q. XII, a. 1, p. 592

\$22 Para los gastos de los estudios y exámenes de bachiller, licenciado y maestro en la Facultad de Artes, véase THuRoT De l'organisation, 61-64. Pero hay que advertir que los datos se refieren al siglo anterior.
} 
De las otras damas de la aristocracia barcelonesa que le habían socorrido, Ínigo mencionaba a tres: a doña Isabel de Josa, a doña Aldonça de Cardona y, en particular, a doña Guiomar Gralla, hija de Juan de Hostalrich y Çabastida, gobernador del condado del Rosellón y mujer de Mosén Francisco Gralla y Desplà, Mestre Racional de Cataluña (cargo del Principado equivalente al de Contador Mayor de Hacienda de Castilla). Ínigo estaba seguro de que, a la Gralla, bastaba informarla para que contribuyera gustosa a la provisión que se le hiciera ${ }^{123}$.

\section{LA PRÁCTICA FINANCIERA DE ÍNIGO}

Como indiqué más arriba, a partir de 1531, ínigo no tuvo que emprender más viajes para obtener recursos para financiar sus estudios y los de sus compañeros pobres o escasos de dinero. Los mercaderes amigos de Flandes, Inglaterra y plazas mercantiles francesas, como podía ser Ruán, giraron sus letras de cambio sobre París, lo mismo que los amigos de Barcelona. Con esta ayuda ínigo pudo atender cómodamente a su propio gasto y al de sus compañeros en apuros ${ }^{124}$.

El giro de letras de los mercaderes sobre París era fácil dada la presencia, en la Villa, de «infiniti mercanti richissimi», en expresión del embajador veneciano Andrea Navagero que la visitó, en 1528 , el mismo año de la llegada de Iñigo $^{125}$. El tráfico comercial entre París y Brabante, especialmente con Amberes, era en ese tiempo muy intenso. En 1529, después de la paz, la circulación entre ambas ciudades se había intensificado, de modo que la peste declarada en el puerto anversano repercutio en las precauciones tomadas en París donde también hubo brotes de pestilencia ${ }^{126}$, a las que Ínigo no fue ajeno. Recuérdese el incidente que narra su autobiografía: entró, con el Dr. Frago, en una casa que decían haber albergado contagiados de peste. Al enterarse, en Santa Bár-

${ }^{123}$ Ignacio a Inés Pasqual. París, 13 junio 1533. MHSI EppIgn I, 90-92 y nota 3. cf. Testimonio de Joan Sagrista Pasqual, Barcelona, 9 marzo 1582, n. [8]. MHSI Fontes narr. III, 191-192. El conocimiento de estas señoras le pudo venir de su trato espiritual con las dominicas del convento de Monte-Sión de Barcelona, donde en 1524, se encontraban monjas con los mismos apellidos: Ferrer, Josa, Çapilla, Desplà y Bojadòs: DUDON 132-133. Aunque no la citaba, por no estar ya en Barcelona, no le faltó, en esta ciudad, la ayuda de doffa Estefanía de Requesens, hija del conde de Palamós y casada, en 1526, con don Juan de Zúniga, comendador mayor de Santiago, ayo del príncipe Felipe y mayordomo mayor de la Casa del Príncipe al constituirse ésta el $10^{\circ}$ marzo 1535.

124 POLANCO Sumario cap. 2, n. ${ }^{\circ}$ 48. MHSI Fontes narr. I, 178-179. P. DE RIBADENEYRA Vita Ignatii Loyolae (en adelante RIBADENEYRA Vita) lib. II, c. 1, $n .{ }^{*} 2$. MHSI Fontes narr. IV, 205.

125 Citado en COORNAERT I, 233

126 COORNAERT 235

Hispania, del Mediterráneo al Atlántico Hispania Sacra 51 (1999) 
bara, los estudiantes huyeron de Íñigo y lo dejaron fuera del colegio, por algunos días, hasta convencerse de que no se había contagiado ${ }^{127}$.

El desempeño económico de línigo, en París, no ofrecía mayor dificultad. En sus viajes de cuestación a Flandes e Inglaterra, había seguido un sistema que combinaba su ideal de pobreza con la práctica común mercantil. La experiencia vivida en el solar de Loyola de la buena administración del patrimonio familiar, por parte de su padre y hermanos, así como su conocimiento de la organización de las finanzas de la Corona castellana, adquirido como familiar del contador Velázquez de Cuéllar, le habían dotado de un sentido financiero.

Ínigo sabía cómo hacer y adoptó los instrumentos vigentes del sistema económico: los depósitos y las letras de cambio. Con ello se ahorraban, por una parte, gastos y riesgos en el transporte de las especies monetarias y, por otra, se aseguraba el dinero en manos de un depositario con garantía, es decir de una banca de depósitos fiable que pudiera responder de las cantidades depositadas. La experiencia de la situación nada deseable en que le puso, a poco de llegado a París, la falta de fidelidad de su compañero español, tuvo que aconsejar a Ínigo la utilización de los instrumentos financieros corrientes más seguros y manejables, sobre todo ahora que había organizado la ayuda a sus compañeros con sus viajes a Flandes.

Así, según noticias trasmitidas por Antonio de Araoz, Íñigo tenía una persona conocida en cada una de las plazas mercantiles y financieras a donde acudía y un depositario general en París. Los mercaderes bienhechores libraban el dinero, a cuenta, al depositario de la plaza respectiva y cada uno de estos entregaba a Íníigo, a su partida, letras de cambio para alguno de los mercaderes de París. A su llegada a esta ciudad, Ínigo las pasaba a su depositario general para su cobranza ${ }^{128}$.

Las ayudas a sus compañeros y a otros estudiantes en apuros, las efectuaba Íñigo mediante la entrega al beneficiario de una letra o cédula para el depositario general de París que se encargaba de abonarla ${ }^{129}$.

\footnotetext{
${ }^{127}$ Autobiografia, cap. VIII, nn. 83-84

${ }_{128}$ Para esta operación financiera, ver ROOVER, 45-50

129 *Qaedam de P. Ignatio...», n. ${ }^{\circ}$ [5]. MHSI Fontes narr. III, 207. Así lo explicaba Araoz: «Y el modo que nuestro Padre tenía de coger estas limosnas y repartirlas, era de desta manera: que non entraba ninguna cosa en su poder, sino que tenfa alguna persona conosçida en el lugar donde estaba, y tenía modo cómo todos le diesen a él por cuenta; y quando llegaba el tiempo de bolverse a París, esta persona en quien depositaba el dinero le daba una letra para algún mercader de París, y esta letra daba nuestro Padre al depositario general de Paris para que la cobrase; de manera que no entraba ninguno dinero desto en su poder. $\mathrm{Y}$ el modo que tenía de repartir este dinero era que a los estudiantes que él váa que tenían necessidad le daba una letra o çédula para el depositario general, en quien estaba el dinero, y él les pagaba. Y desta manera distribuya la limosna que con su travajo avfa buscado, sus-
} 
De este modo, ínigo pudo socorrer a muchos sin necesidad de guardar personalmente el numerario ni exponerlo a pérdida inútilmente. Esto era tener más sentido de la pobreza que no el no tocar una sola moneda, como interpre$\tan$ la frase de Araoz - «no entraba ninguno dinero en su poder» ${ }^{130}$ - los autores que lo comentan ${ }^{131}$, sin reparar en que Íniigo utilizaba el sistema y la práctica común mercantil de las operaciones financieras. Como explica el profesor Carande, citando un documento algo posterior, pero que se puede aplicar a toda la época, relativo a estas operaciones: «nadie toca dinero alguno que permanece en el banco» ${ }^{132}$.

Por el tenor de los documentos que nos informan de esta actividad económica en relación con la obtención de recursos por parte de f́ñigo para sí y sus compañeros, podemos concluir que se trataba de auténticas prácticas financieras al uso. El depositario de confianza ejecutaba las operaciones propias de un banquero: depósito y retirada de numerario, crédito, pago y recibo de dinero por transferencia entre dos cuentas de la misma banca o entre dos bancos, etc. Estos depositarios serían los mismos que utilizaban los mercaderes amigos para sus transacciones.

Las letras de cambio que el depositario de cada plaza entregaba a ínigo por el montante de las cantidades libradas a cuenta, o las que los mismos bienhechores giraban a Ínigo de Barcelona o Flandes sobre París, exigían normalmente el cambio a moneda corriente, sujeto a la fluctuación propia del mercado dinerario, que efectuaba el depositario general, o banquero, de París. En el caso de consistir estas letras en cédulas obligatorias o letras de feria, en uso en Brujas junto con las letras de cambio, ofrecían la ventaja de su carácter de valor instrumental para una cómoda circulación de capitales, especie de papel moneda que podía transferirse a terceros ${ }^{133}$. Pero de todos modos, los beneficiarios de Ínigo necesitaban recibir la moneda coniente para sus gastos ordinarios.

Las cédulas o letras que Íñigo, como dador, entregaba a los beneficiarios, como tomadores, para su depositario de París, consistían prácticamente en ordenes de pago que debían ser registradas en el libro de diario, con lo que fñigo podía controlar los gastos y las existencias, es decir el haber y el debe. El

tentando muchos necesitados, y para sí, como lo saben todos, proveýale una sefiora de Barcelona de una cierta cantidad cada anno.»

130 Qadam de P. Ignatio... n. [5.']. MHSI Fontes narr. III, 207.

131 G. VILLOSLADA comenta: «Recogía dinero, ciertamente, pero él, amante siempre de la pobreza y exacto imitador de S. Francisco, no quería tener monedas a su alcance, ni siquiera tocarlas" Nueva biografía 312

132 Carande 1, 522-523

133 Para la originalidad de las letras de cambio de Brujas y Amberes, véase: BRAUDEL 3, 128-129, ROOVER 95-99, VAN HOUTTE 197-198, VAN DER WEE 338-347, COORNAERT II, 166-171

Hispania, del Mediterráneo al Atlántico Hispania Sacra 51 (1999) 
banquero, por lo general, no cobraba nada al cliente por las operaciones cuentacorrentistas ${ }^{134}$.

\section{LOS VIAJES DE CUESTACION DE ÍNIGO, UN CASO DE CONCIENCIA}

No todos entendieron o aprobaron los viajes de Î́nigo en busca de limosnas, sobre todo el último a Inglaterra, y lo criticaron en razón de la deshonra que suponía, para Íñigo, el mendigar dado su origen familiar. Según una tradición, consignada por el historiador de la Compañía, del siglo XVII, Daniel Bartoli ${ }^{135}$ y recogida por los Bolandistas el siglo siguiente ${ }^{136}$, un tal Juan Madera, paisano de İnigo, hizo de ello escrípulo de conciencia y trató de convencerle que hacía mal en viajar a un país tan lejano (Inglaterra) para darse a conocer como persona reducida casi a extrema indigencia. Ello suponía una gran deshonra y vituperio para los de la Casa de Loyola que aparecían, o tan pobres que no tenían con qué subvenir a su necesidad, o tan tacaños y avaros que, teniendo, lo abandonaban.

Madera intentó persuadirle de que su conducta era un grave pecado de injusticia manifiesta contra su familia de la que no era dueño. Iñigo habría tratado de convencerle de lo contrario, sin resultado y, a la postre, había sometido el caso al parecer de los mejores té́logos de la Sorbona, no tanto en razón de su propia conciencia, sino para satisfacer la ajena. Les presentó el caso de conciencia, por escrito, pidiéndoles asimismo su respuesta escrita. Este fue el planteamiento: «si un caballero que, por amor de Dios, había renunciado al mundo, podía, sin escrípulo de infamar su Casa, andar por varios países buscando limosnas». La respuesta unánime de los doctores fue que no había sospecha de culpa alguna. f́ñigo, según la noticia de Bartoli, mostró el dictamen al escrupuloso -o tentador- Madera, haciéndole ver el valor de la pobreza voluntaria por amor de Dios que, ennoblecida por Cristo que la escogí, no podía denigrar el esplendor de la familia más ilustre del mundo.

Pero el caso, si es que se planteó y resolvio después del viaje a Inglaterra, no tuvo aplicación inmediata. Íñigo no necesitó emprender más viajes que le expusieran a nuevas críticas. El incidente indica, por otro lado, que el linaje

\footnotetext{
134 CARANDE 1, 321. Esta era la norma en Espafia, por pragmática de los Reyes Católicos, en Alcalis, a 17 de enero 1501, revocando la anterior que permitfa el interes del $5^{\circ}$ \%o: el banco «no puede llevar ninguna cosa de las personas que en él ponen moneda ni de las a quien hace pagar por libranzas a él hechas, asi librándose al contado, como en otra particular maneras: Nueva Recopilación de las leyes de España ley V, tit. XVIII, lib. V.

135 D. BARTOL Della vita e dell'Istituto di S. Ignatio fondatore della Compagnia di Giesù libri cinque. Roma 1650, Lib. I \$ 36, p. 132-133

${ }^{136}$ Acta SS. Iulii VII \& XVI, p. 438 e.f.
} 
familiar de Íñigo era ya conocido entre los mercaderes que frecuentaba y, en especial, por los de su región.

\section{LOS COMPAÑEROS BENEFICIARIOS}

Las cantidades recaudadas en sus viajes debían ser cuantiosas. Así lo indica Araoz: «solía coger mucha limosna ... le daban buenas limosnas» ${ }^{137}$. Polanco afirmaba que, de sus viajes a Flandes, «traía para pasar después cómodamente todo el tiempo del año» y, a partir del tercer año, con lo que le enviaban de allá y de España «vino a tener comodidad de entretenerse a sí y ayudar aun a otros» ${ }^{138}$. Diego Lainez era también explícito al tratar de la provisión ordinaria remitida de España y de lo conseguido en Flandes: con estos dineros «vivía él y ayudaba etiam temporalmente a diversas personas» ${ }^{139}$.

Con los 100 ducados de Bárcelona, Ínigo podía contar, además de la cantidad necesaria para sí mismo, con el equivalente de otra beca completa de 50 ducados o dos de 30, según lo que he explicado.

Entre los beneficiarios de estas ayudas se encontraban sus dos primeros compañeros de Santa Bárbara: Pedro Fabro (o Le Fèvre) y Francés de Xavier. Fabro, según recordaba en sus memorias, compartía con Ínigo habitación, mesa y bolsa (in eodem cubiculo, eadem mensa, eadem bursa) ${ }^{140}$. Polanco explica que f́ñigo «se hizo amigo a Fabro ayudándole en lo temporal». A Xavier, además de la ayuda espiritual y sus consejos, le favoreció durante su regencia en el colegio de Dormans-Beauvais, proporcionándole oyentes y le socorrí́ económicamente en circunstancias penosas en que padeció verdadera necesidad y pobreza, desprovisto de la ayuda familiar ${ }^{144}$.

En cuanto al término cubiculum (habitación), otro de los compañeros de Íñigo, el fidalgo portugués Simão Rodrigues de Azebedo, colegial de Santa Bárbara desde 1527, becado del rey de Portugal y el cuarto en unirse a f́ñigo, aclara que los tres primeros - fínigo, Fabro y Xavier- vivían, en el colegio,

\footnotetext{
137 Qadam de P. Ignatio... n. ${ }^{\circ}$ [5]. MHSI Fontes narr. 3, 207

138 POLANCO Sumario cap. 2, n. ${ }^{\circ}$ 48. MHSI Fontes narr. I, 178-179

139 Laínez a Polanco. Bolonia, 16 junio $1547, \mathrm{n} .^{\circ} 27$. lbidem $1,97 .^{\circ}$

140 Memoriale Bti. Petri Fabri S.I. Fragmentum, n. ${ }^{\circ}$ 8. MHSI Fontes narr. I, 32-33

14] Xavier a su hermano Juan de Azpilicueta (o Azpilcueta). París, 25 marzo 1535. MHSI Epistolae S. Francisci Xaverii aliaque eius scripta. Ed, G. SCHURHAMMER et J. WICKI. 2 vols. Romae 1944-1945 (en adelante EppXav). 1, 9-10. Para las dificultades económicas del señor de Xavier, véase SCHURHAMMER Javier I, 225-226.
}

Hispania, del Mediterráneo al Atlántico Hispania Sacra 51 (1999) 
en una misma casa, pero en cámaras separadas ${ }^{142}$. Lo confirmaba el «barbista» portugués, Antonio Pinheiro, futuro obispo de Miranda y luego de Leiria, que convivió con Ínijo en la misma casa. Era una torre con tres sobrados: Ignacio escogio la parte alta como el mejor sitio para el estudio, debido a su mayor tranquilidad y ausencia de ruidos ${ }^{\mathrm{I43}}$. Al piso alto de esta torre subió el navarro, Miguel de Landibar (iur. 1534-35), fámulo de Xavier, con ánimo de apuñalar a f́nigo, enfurecido por el cambio producido en su amo después de hacer los ejercicios espirituales ${ }^{144}$.

Además de Fabro y de Xavier, disfrutaban de la ayuda de Iñigo otros estudiantes que se le unieron poco después. Entre ellos, Alfonso Salmerón -amigo de Lainez y su compañero de viaje a París- y Nicolás Alfonso de Bobadilla. Los tres procedían de la Universidad de Alcalá, donde habían oído hablar de fñigo. Lainez y Salmerón llegaron a París en otoño de 1532, Bobadilla al año siguiente.

Diego Lainez, hijo de Juan Lainez Coronel, de origen converso, estaba bien provisto por su familia. Con todo, Íñigo, en la primera ocasión que le encontró en su propia posada, se permitió aconsejarle también en asuntos temporales, lo que le granjeó su estima ${ }^{i 45}$.

142 Relación de Simão Rodrigues a Mercurián. Lisboa, 25 julio 1577, cap. I, n. ${ }^{\circ}$ [5]. MHSI Fontes narr. III, 13. Esta es su afirmacion: «quando isto aconteceo [sendo estudantes] pousavä̀o juntos no Collegio de Santa Barbara em uma casa, mas en camaras destintas»

143 Pinheiro lo comunicó al P. Francisco de Araujo quien lo dejo consignado en un memorial sobre los origenes de la Compafía en Portugal. Afirmaba: «Erăo as cazas de tres sobrados, o santo morava no mais alto, e os estudantes trazixo en pratica, que o sobrado mais alto era o paraizo, o do meyo o Purgatorio, o último o Inferno, pella desinquietação que neste bayxo havia, que mestre Ignacio escolhera o de sima por mais quietos ANTONIO FRANCO lmagem da virtude em o Noviciado da Companhia de Jesu na corte de Lisboa. Coimbra 1717, p. 22. SCHURHAMMER Javier 102-104

144 SCHURHAMMER Javier 243-244

145 POLANCO Sumario cap. 2, n. $^{\circ}$ 52. MHSI Fontes narr. I, 182. Véase M. SCADUTO L'epoca di Giacomo Lainez. $l$ govemo (1556-1565) (Roma, 1964) 125-127. Había nacido en Almazán hacia 1512. Su madre, Isabel Gómez de León, era originaria de Sigüenza. Ribadeneyra califica a ambos progenitores de epersonas ricas, honradas y cuerdas y por extremo inclinadas a la piedad» PEDRO DE RibadeneYra Vida del P. Maestro Diego Lainez en Historias de la Contrarreforma p. 459. Para la ascendencia judeoconversa de Lainez: C, CARRETE PARRONDO, C. FRAYLE CONDE Fontes Iudaoorum Regni Castella IV. Los judeoconversos de Almazán. 1501-1515. Origen familiar de los Lainez. Salamanca. Universidad 1987. Otros datos en ENRIQUE SANZ Los Lainez y la limpieza de sangre en Un Centenario. Padre Enrique Basabe Terreros. 1893-1993 Perficit. Publicación de Estudios Clásicos Textos y Estudios, 1987-1993 (Segunda Serie) XVII, Salamanca 1993, pp. 65-71. Para la opinión de Ignacio de Loyola y de otros primeros jesuitas sobre Diego Lainez y su elogio, en el contexto de su origen judeoconverso, véase F.B. MEDINA Ignacio de Loyola y la «limpieza de sangre» en J. PLAZAOLA (ed.) Ignacio de Loyola y su tiempo. Congreso Intemacional de Historia (9-13 Septiembre 1991). Universidad de Deusto. Bilbao 1992, 579-615; 605-606 
Bobadilla llegó a París por otoño de 1533. Natural de Bobadilla del Camino (Palencia), de donde tomó el apellido topónimo de origen, era hijo de Francisco Alfonso, converso según se decía ${ }^{146}$. Polanco afirma que el universitario palentino, con pocos recursos económicos, inició su contacto con Íñigo por su fama, aún viva en Alcalá, de ayudar a los estudiantes a encontrar una digna sustentación. Î́nigo le favorecio, procuró que hallase comodidad para sus estudios y le consiguio, por medio, al parecer, de Castro, una regencia en el colegio de Calvi junto a la Sorbona ${ }^{147}$. Alfonso Salmerón, toledano, cristiano viejo, pudo ser otro de los beneficiarios. Según noticias de Ribadeneyra, sus padres eran «pobres, pero limpios y virtuosos» ${ }^{148}$. Todos tres --Lainez, Salmerón y Bobadilla-- eran porcionistas de Santa Bárbara.

En 1532, Iñigo ofrecí a su hermano Martín García de Oñaz, señor de Loyola, ocuparse de su sobrino Millán, en caso de enviarlo a París, tanto en lo académico y espiritual como en su manutención. Martín, al parecer, no podía hacer frente, en ese momento, a la costa anual del hijo y había pedido a su hermano que le relevase de esa obligación, si hubiese oportunidad. Al menos, Íñigo así lo entendi $6^{149}$.

\section{GESTIONES EN ESPAÑA EN FAVOR DE SUS COMPAÑEROS}

El viaje de Íñigo a España en 1535, organizado por sus compañeros, tuvo como objeto, además de recuperar su salud, arreglar asuntos familiares y económicos de aquéllos, en particular de Lainez, Salmerón y Xavier. Habían quedado con Íńigo en reunirse con él en Venecia para emprender juntos la pere-

146 cf. Araoz a Ignacio. Madrid, 14 enero 1552. MHSI EppMixtae 2, 656. Araoz, en el calor de la polémica con el arzobispo toledano Silíceo sobre la introducción de un estatuto de limpieza de sangre en la Compañía, informaba a Ignacio: «Vno me dixo que sabía de çierto que Mtre. Bobadilla era hijo de vn tornadizo, id est que por sus pyés fue a la pila, ut aiunt». MODESTO SALCEDo Un gran palentino frente a la Reforma: el P. Nicolás de Bobadilla (Palencia 1982) cita este texto sin aportar nuevos datos. Nacido hacia 1509, Bobadilla afirma, en su autobiografía, resaltando la epiedad» de sus progenitores: «ibique [Bobadilla deI Camino] nutritus et educatus a devotis christianis parentibus suis, scilicet Francisco Alphonso et Catherina Pérez, qui educarunt illum in timore Domini, frequentando ecclesiam cum magna pietate». MHSI Fontes narr. III, 323

147 POLANCO Sumario cap. VII, n. 52 . MHSI Fontes narr. I, 182. LARRAN̈AGA nota 49, 373-375. BARTOLI cita expresamente a Bobadilla, junto a Fabro, como beneficiario de las limosnas de frnigo I, 176

148 RIBADENEYRA Vida y muerte del P. Alfonso Salmerón en Historias de la Contrarreforma, 587. Nacido en 1515, era el más joven de los compañeros de Ignacio. Sus padres, Alfonso Salmerón y Marina Diaz, procedían de las aldeas toleđanas de Olías y Magán.

149 Ignacio a Martin García de Oxaz. París, febrero 1532. MHSI EppIgn I, 78-79. Estas son sus palabras: «en lo que a justicia y a razón toca, no creo que Dios N.S. me dexará faltar, pues solo su santísimo seruicio me mueue, vuestro descanso por él y prouecho de vuestro hijo, si así hordenárades hazer»

Hispania, del Mediterráneo al Atlántico Hispania Sacra 51 (1999) 
grinación a Jerusalén, en virtud del voto de Montmartre (15 agosto 1534): pasar a Jerusalén para gastar la vida en provecho de las ánimas. Esperarían embarcación en Venecia durante un año y, en caso de no haberla, irían a Roma y se pondrían al servicio del papa para ser enviados a donde le pareciera al pontífice haber mayor necesidad espiritual.

En fuerza del voto de pobreza evangélica, emitido en Montmatre, debían proceder a la renuncia de sus bienes y, al mismo tiempo, hacer frente a los gastos de la terminación de los estudios en París y a los del viaje a Tierra Santa. El envío del dinero de los compañeros a París, lo ajustó Íníigo con el padre de Diego Lainez, que ofrecía garantías de transferencia por vía segura.

Ínigo debía visitar a las familias de Xavier en Navarra, de Lainez en Almazán y de Salmerón en Toledo ${ }^{150}$. En cuanto a Francés de Xavier (así se firmaba), como su hermano Miguel de Jassu, señor de Xavier, no hacía frente a los gastos de los estudios, como debía en razón de su obligación de mayorazgo, a causa de la precaria situación económica de la casa, se vio obligado a acudir, en petición urgente de ayuda, al segundogénito, el capitán Juan de Azpilcueta. Estaba casado con Juana de Arbizu, viuda rica, señora de Sotez y Aoz y del palacio de Obanos, donde residía. A Obanos encaminó Xavier a Íñigo, con cartas de recomendación en su favor deshaciendo las especies siniestras que corrían contra f́ñigo. Xavier explicaba a Juan su propia situación precaria: siempre le faltaba lo necesario. Podía informarse del «Señor Íñigo» acerca de sus «necessidades y trabajos mejor que de persona del mundo», por estar al cabo de sus «miserias y lacerias más que de hombre del mundo» y haberle «favorescido muchas veces con dineros y amigos» ${ }^{151}$.

Tenía también intención de ganar a sus antiguos compañeros que había dejado en Salamanca. Ya se ha indicado el fin de Lope de Cáceres y Calixto de Saa. En Madrid, f́ñigo visitó la Casa del Príncipe, el futuro Felipe II, niño entonces de 8 años. En la Casa se encontraba colocado su antiguo compañero, el Licenciado Juan de Arteaga y Avendaño, comendador de Santiago y futuro obispo de Chiapas, en Nueva España. Era preceptor de Don Luis de Requesens, hijo de Don Juan de Zúñiga, ayo y mayordomo mayor del Príncipe y de doña Estefanía de Requesens, una de sus devotas de Barcelona. La aya del Príncipe era Leonor de Mascarenhas, otra de sus devotas. Años más tarde, en 1556, aún en vida de Ignacio, el mismo Felipe II declaró, en Amberes, al entonces conde de Feria, Gómez de Figueroa, que conocía «muy bien» a Ignacio «cuando iba vestido de pardillo, que iua algunas veces a visitar a doña Leonor

150 Autobiografia cap. IX, n. 90 . LARRAÑAGA 422-431, notas 17-19

$15 !$ Francisco Xavier a su hermano Juan de Azpilicueta (o Azpilcueta). París, 25 marzo 1535. MHSI EppXav I, 9-10. Para la situación precaria del señor de Xavier, SCHURHAMMER Javier 225-226 
de Mascareñas que le criaua» ${ }^{152}$. En 1586, al contemplar el rey el retrato de Ignacio de Loyola, entre las obras que le mostraba el pintor de corte, Alonso Sánchez Coello, le alabó por haberlo pintado tan al vivo, asegurándole que se le parecía mucho. Lo había conocido en Madrid, aunque entonces -según el rey- llevaba Ignacio más barba ${ }^{153}$.

\section{LOS GIROS A ITALIA}

Ínigo, como he indicado, giró el dinero a sus compañeros de París por medio de Juan Lainez Coronel al tiempo que procuraba financiar sus propios gastos personales en Bolonia, en cuya Universidad pretendía terminar sus estudios teológicos y a donde llegó a mediados de diciembre de 1535 muy maltrecho. No encontró ayuda fuera del colegio de San Clemente de los Españoles, donde le atendieron. Ś́lo permaneció en Bolonia quince días, de los que siete en cama «con dolor de estómago, fríos y calenturas». El clima malsano le hizo encaminarse a Venecia. Como en París, también en Italia dependió del apoyo de sus amistades de Barcelona. A su llegada, recibió (quizás todavía en Bolonia) 12 ducados a cargo de Isabel Roser quien le prometio, poco después, girarle sobre Venecia, para abril, la provisión suficiente para terminar sus estudios. A juicio de fínigo, esta era la mejor solución pues tendría para todo el año y podría surtirse de libros y de otras cosas necesarias. Así lo comunicaba, en febrero de 1536, a su amigo catalán, el arcediano de Barcelona y su futuro obispo, Jauma Caçador, que también le había hecho llegar su «limosna» y le ofrecía enviarle «la acostumbrada porción» cuando Înigo le avisase. La tierra era cara, pero gozaba de buena salud y no pasaba indigencia ni trabajos corporales «más de los que el estudio trae consigo». Estaba «asaz proueýdo» con lo enviado por la Roser y Caçador y «en compañía y casa de un hombre mucho docto y bueno» ${ }^{154}$.

\footnotetext{
152 Ribadeneyra a Ignacio de Loyola. Amberes, 20 febrero 1556. MHSI Ribadeneira I, 154

153 Relación de la forma que se trvo en hazer el retrato de nuestro Santo P. Ignacio de Loyola y del motivo que para ello tuvo el P. Pedro de Ribadeneyra, hecha por el H. Crhistobal Lopez, su compantero, que se hallo a ello. MHSI Fontes narr. III, 239-249; 245. Autobiografia cap. IX, n. 90. LARRAÑAGA 428-431 nota 20

154 Ignacio a Caçador. Venecia, 12 febrero 1536. MHSI EppIgn I, 93-94. No consta con certeza de su huésped en Venecia. Se dan los nombres de Pietro Contarini, procurador del Hospital de los Incurables y, con mucho mayor fundamento, el de Andrea Lippomani, de la Orden Teutónica, comendador de Santa María Magdalena de Padua y prior de la Santísima Trinidad de Venecia: G. VILLOSLADA Nueva biografia 401-402
}

Hispania, del Mediterráneo al Atlántico Hispania Sacra 51 (1999) 


\section{LOS MAESTROS POBRES DE PARÍS}

Íñigo y sus compañeros - llegados a Venecia hacia 1537 después de obtenidos sus grados en la Universidad de París-, habían realizado el viaje a Italia como pobres clérigos, viviendo de la caridad. También el presupuesto del viaje a Jerusalén (flete de la nao y derechos exigidos por la Sublime Puerta) lo financiaron con donativos que no quisieron aceptar, en contante, sino en pólizas o letras de cambio giradas de Roma sobre Venecia: 60 ducados del Papa Paulo III (en dos partidas) y más de 150 ducados procedentes de cardenales y otras personas, en particular españoles, de la corte pontificia. Reunieron, según Íñigo, 260 ducados ${ }^{155}$.

El día de San Juan de Junio de 1537, esto es, el 24, se ordenaron sacerdotes, en Venecia, siete de los nueve primeros compañeros de París, entre ellos Íñigo (Pedro Fabro ya lo era y Alfonso Salmerón no tenía la edad reglamentaria). Antes de la ordenación, hicieron libremente voto de pobreza voluntaria perpetua en manos del legado pontificio Jerónimo Verallo. De acuerdo con el tenor de las cartas dimisorias, dadas en Roma por el Penitenciario Mayor, cardenal A. Pucci, que no hacían mención del título de patrimonio 6 beneficio, el legado les dio a escoger el título de la ordenación: ad titulum voluntaria paupertatis o ad titulum sufficientis litteraturace o ad titulum vtriusque. La decisión de Íñigo y sus compañeros fue todo un símbolo de lo que sería el proyecto de la futura Compañía de Jesús: escogieron ordenarse ad titulum vtriusque. Nada les exigieron ni en Roma, por las licencias y cartas dimisorias, ni en Venecia, por las ordenes y las amplias licencias ministeriales otorgadas por el legado en todo el dominio veneciano: «todo gracioso sin llevar dineros» ${ }^{156}$.

155 Ignacio a Juan de Verdolay. Venecia, 24 julio 1537. MHSI EppIgn I, 118.122. Dice Ignacio: ales dio [el papa] al pie de sessenta ducados de limosna; y entre cardenales y otras personas que allí eran les dieron más de 150 ducados; de manera que traxeron aquí en zédulas 260 ducados». La suma total hace $\mathbf{2 1 0}$ ducados, la misma cantidad que consignan, en valores monetarios equivalentes, dos de los compañeros que habían recibido la limosna en Roma: Simão Rodrigues: 210 cruzados (Rodrigues a Mercurián, Lisboa, 25 julio 1577. MHSI Fontes narr. III, 81) y Diego Lainez: 210 escudos (Lainez a Polanco. Bolonia, 16 junio 1547. lbidem 1, nn. 39-40, 116 y nota 10). A menos que la expresión de frigo -«más de 150 ducados»- supusiera otros 50 más de limosna de diversa procedencia, el cálculo de los 260, está errado. La Autobiografía (cap. X, n. ${ }^{\circ} 93$ ) es más imprecisa: «Li compagni venero da Roma con police di 200 o 300 scudi, li quali gli furono dati per elemosina per pasare a Hierusalem; et loro non gli volsero pigliare senon in police»

156 Ignacio a J. de Verdolay. Venecia, 24 julio 1537. MHSI EppIgn I, 121. Como Maestros de París y hombres de confianza, el legado les concedió amplísimas fácultades: «Assi todas estas cosas acauadas, assi en Roma como en Venecia, gracioso sin lleuar dineros, nos dio el mesmo delegado autoridad cumplida para que en todo el dominio de Venecia pudiéssemos predicar, enseñar y interpretar la escritura publice et priuatim; assímesmo confessar y absoluer de casos episcopales, de arzobispos y patriarchas" 
No hubo ese año navegación a Tierra Santa, debido a la constitución de la Santa Liga - el papa, Venecia y el emperador - y la guerra contra el Turco, por lo que, al año siguiente -1538-, entró en vigor la segunda parte de la cláusula del voto de Montmartre: ponerse, en Roma, a disposición del Pontífice. Como primera providencia, Íñigo y sus compañeros, por medio del Dr. Pedro Ortiz (antiguo conocido de París), devolvieron a los donantes las pólizas de los 260 ducados, pues los habían pedido exclusivamente para el viaje y querían actuar de acuerdo con la pobreza voluntaria que habían prometido: «porque ninguno piense - declaraba Ignacio-que tenemos hambre ni sed de las cosas por las quales el mundo muere» ${ }^{157}$. Por ello, Íñigo también devolvió a su huésped de Valencia, Martín Pérez de Almazán, los cuatro ducados de oro entregados para su peregrinación ${ }^{158}$.

La Compañía de Jesús nacía en germen: Maestros de París ordenados a título de pobreza voluntaria y de suficiencia de letras que les facultaba para enseñar ubique terrarum. Los dos polos del proyecto ignaciano, que los primeros compañeros habían hecho propio, se centraban en dos términos al parecer opuestos: letras y pobreza. S6́lo que, para cubrir las etapas que conllevaba el primer término - -los estudios - y su financiación, había que arbitrar el régimen del segundo - la pobreza voluntaria - mientras durasen aquéllos.

El régimen económico de la etapa universitaría era, para Íñigo, transitorio, de preparación para predicar en pobreza, aspecto esencial a la «vida apostólica» común a los movimientos de reforma. Este había sido su propósito, como lo expresaba, desde Venecia, en febrero 1536, a Jauma Caçador que le manifestaba su deseo de oírlo predicar públicamente en Barcelona ${ }^{159}$. Para alcanzar su propósito, f́ñigo se preparó en las mejores universidades, para lo que necesitó disponer de un fondo económico seguro que le permitiera comodidad para

${ }^{157}$ Ignacio a Juan de Verdolay. Venecia, 24 julio 1537. MHSI EppIgn I, 121. Lainez a Polanco. Bolonia, 16 junio 1547. MHSI Fontes narr. I, n. ${ }^{\circ} 39,116-117$. Así también la Autobiografia cap. X, n. 93: «le quali [i compagni] dipoi, non potendo andare in Hierusalem, gli rendetero [le polici] a quelli che gli avevano dati.

${ }_{158}$ Acta Patris Ignatii scripta a P. Lud. Gonzalez de Camara 1553/1555, cap. LX, n. 89 nota 12. MHSI Fontes narr. II, 486-487

${ }^{159}$ Ignacio a Caçador. Venecia, 12 febrero 1536. MHSI Epplgn I, 96. f́nigo también lo deseaba, pero no por la gloria de hacer lo que otros no podían, ni conseguir lo que otros habían alcanzado, sino, «como persona menor», su predicación sería sencilla, de cosas inteligibles, más fáciles y menores, poniendo su esperanza en Dios que le daría su gracia para, en esas menores, poder aprovechar para su mayor servicio y alabanza. Le faltaba aún un af́o de estudio, pero, acabado, se entregaría a proclamar 1a palabra de Dios - «ablar la su palabra»- en Barcelona, antes que en ningún otro lugar de Espanfa, a no ser que la providencia le pusiera fuera de España. Conclúa: «mas siempre en estado de predicar en pobreza, y no con la largueza y embaraços que, al presente, con el estudio tengo. Como quiera que sea, en sefial de lo que dígo, acabado mi estudio, luego ynbiaré allá donde estáis, los pocos libros que tengo y tubiere, porque así tengo ofreçido a Isabel Roser de se los ynbiar»

Hispania, del Mediterráneo al Atlántico Hispania Sacra 51 (1999) 
el estudio. Ese fondo lo creó sobre la base de recursos conseguidos en el círculo de mercaderes adinerados que le consintió también subvenir a las necesidades de sus camaradas y compañeros. La pobreza voluntaria elegida por Íñigo durante sus estudios se basaba en la dependencia de la liberalidad y buena voluntad de sus bienhechores, en la propia generosidad con sus compañeros alcanzados y en la disposición, como administrador y no como dueño, aunque lo fuera, de los recursos procurados con su mendicidad en beneficio de los otros compañeros. Esa había sido su práctica anterior cuando la ejercía materialmente después de su conversión: compartir con otros mendigos las limosnas recibidas, o pedirlas expresamente para ellos ${ }^{160}$.

\section{LA FINANCIACIÓN DE LOS COLEGIOS DE LA COMPAÑÍA DE JESÚS}

La confianza en la providencia, basada en la palabra evangélica, había sido para él, desde su cambio de vida en Loyola, la piedra angular de su pobreza voluntaria al estilo de la llamada «vida apostólica». Por ello, no era partidario de atesorar, sino de contentarse con una «porción» anual. Así lo hizo saber a Isabel Roser a proposito de la letra de 20 ducados enviada, en 1532, por mano del Dr. Benet y proveniente de la buena voluntad de sus bienhechoras ${ }^{161}$.

Sin embargo, no será una «limosna anual» la que Ignacio va a establecer para mantener a los futuros estudiantes de la Compañf́a. Ésta tomará a su cargo la manutención del «escolar», de modo que pueda entregarse al estudio a tiempo completo, como su principal tarea, pero, a su vez, le exigirá la renuncia de sus bienes 0 , al menos, de su administración y aceptar, a cambio, la provisión que se le ofrece en común, dejando que otros se ocupen de él.

Su propia experiencia le llev6 a sentar los principios que deberían regir el régimen económico para la atención de los estudiantes de la Compañía: una renta estable para el colegio donde residieran éstos y los otros miembros de la Compañ́a encargados de su formación u ocupados de los ministerios sacerdotales en la iglesia del colegio. Así se estableció en las Letras Apostólicas de Paulo III Regimini militantis Ecclesiae (27 sept. 1540) y en las de Julio III

160 Ver p. ej., Autobiografía caps. IV, n. ${ }^{\circ} 40 ;$ V, n..$^{\circ} 0$ y VI, n.. 57. Testimonio de Joan Sagristà Pasqual. Barcelona, 9 marzo 1582, nn. [4] [6] [8] y [12]. MHSI Fontes narr. III, 189190195

161 Ignacio a Isabel Roser. 10 noviembre 1532. MHSI EppIgn I, 83. Estas son sus palabras: «Aunque Leonor Zapila se me offrece en su carta, y muestra tener voluntad para ayudarme, por agora no me parece escreuirla para ayudarme para el estudio; porque no tenemos seguro si llegaremos de aquí a vn año: si allá llegáremos, Dios N.S. nos dará entendimiento y juyzio, con que más le podremos seruir, y acertar siempre en su querer y voluntad» 
Exposcit debitum (21 julio 1550) ${ }^{162}$ y quedó declarado en las Constituciones. Ignacio, de acuerdo con las Letras Apostólicas citadas, confí al Prepósito General y a la Compañía Profesa la administración de los bienes de los colegios en el supuesto de que, al no poderse lucrar ni uno ni otra de esas rentas en beneficio propio, procederían de modo más honrado y justo para mayor servicio de Dios y buen gobiemo de los colegios ${ }^{163}$.

Polanco afirma expresamente la conexión entre las dificultades económicas experimentadas por Íñigo durante su estudios y su decisión de establecer este régimen de pobreza de los' colegios de la Compañía. Las otras dos dificultades o impedimentos para el estudio - la excesiva devoción y la salud deficientetambién trató de remediarlas en los estudiantes de la Compañía: para la primera, impuso la moderación del tiempo dedicado a la oración y ejercicios de piedad; la segunda trató de solucionarla con el establecimiento, en los colegios, de un prefecto de salud que se ocupara de mantenerla, la salubridad de los parajes donde debían ubicarse los colegios, la adquisición de huertas para su expansión el día de descanso semanal y un especial cuidado de los enfermos, aunque hubiera que venderse parte del ajuar del colegio ${ }^{164}$.

La seguridad económica respaldada por rentas fijas era, pues, en la mente de Ignacio, el régimen más idóneo para la completa dedicación al estudio. Pero, en su falta, recurrirá, como en los tiempos de París, a la recaudación de fondos confiando en la providencia y acudiendo a los que podían y querían contribuir con sus bienes. Es lo que hizo para subvenir a la penuria de los estudiantes del Colegio Romano, fundado en febrero 1551 por el duque de Gandía Francisco de Borja, durante los primeros años de su existencia coincidentes con la crisis económica europea (1551-1556).

162 Institutum Societatis lesu 3 vols. (Florentia 1886-1891). I. Bullarium et Compendium Privilegionum cols. 4a 23b-24a.

${ }^{163}$ Examen c. 1, n. ${ }^{\circ} 4$; Constituciones, P. 4, c. 2, n. ${ }^{\circ} 5$ y c. 10, n. 1 . MHSI Monumenta Ignatiana. Series Tertia. Sancti Ignatii de Loyola Constitutiones Societatis Iesu I. Textus Hispanus. Roma 1936. pp. 9 396-397 452-453. La Compañía Profesa (es decir los profesos de votos solemnes y sus coadjutores) no podía vivir de rentas, sino de limosna. Para la cuestión de los colegios puede verse L. LUKÁCS De origine collegionm externorum deque controversiis circa eonm paupertatem obortis. AHSI 29 (1960) $189-245 ; 30$ (1961) 1-80

164 POLANCO Vita, cap. VI, n. ${ }^{\circ}$ 56. MHSI Fontes narr. II, 558. Estas son las palabras del secretario de Ignacio: «Ex his difficultatibus, quas studionum tempore in victu et rebus vitx necessaris quarendis Ignatius expertus est, hanc sententiam in animo suo statuit: expedire ut qui litteris darent operam de victu solliciti non essent; et ita in institutione Societatis, quamvis paupertatem in communi et in particulari in domibus retinendam censuisset, Collegi, in quibus nostri studis operam darent, redditus ad eorum sustentationem habere debere sensit, et in Apostolicis litteris et Constitutionibus Societatis id ita prascribi curavits.

Hispania, del Mediterráneo al Atlántico Hispania Sacra 51 (1999) 


\section{SENTIDO IGNACIANO DE LA FUNCIÓN SOCIAL DEL DINERO}

En último término, lo que caracteriza el proyecto de Íñigo en la financiación de los estudios de París y su posterior proyección en la organización económica de los colegios de la Compañía de Jesús es, ante todo, su convencimiento de la necesidad del estudio serio para un ministerio sacerdotal acorde con las exigencias de un mundo en transformación y, junto a ello, su preocupación por la libertad del estudiante para su entera dedicación a su formación universitaria sin estar sometido a otras presiones que se lo impidieran, ya fuera manutención, alojamiento, lejanía de las Escuelas, escasez de libros etc.

Su propia experiencia le capacitaba para comprender, en sus compañeros, la misma problemática a la que había tenido que enfrentarse, por lo que procuraba resolverla con sus consejos y su industria en favor de los otros. Se sirví́ de sus conocimientos personales - antiguos o recientes- y de sus cualidades de relaciones humanas para facilitar a sus condiscípulos alojamiento conveniente en los colegios parisienses de modo que pudieran estudiar con comodidad, como él mismo la buscó para sí en el colegio de Santa Bárbara, incluso escogiendo una habitación en la planta superior más acomodada al estudio por su mayor tranquilidad. Les agenció ayudas económicas de diversa índole y, como en los casos mencionados de Xavier y Bobadilla, les consiguió empleos de regentes y discípulos que les oyeran.

Para costear los gastos que todo ello acarreaba a los estudiantes sin recursos y dispensar otras ayudas extraordinarias, f́ñigo acudió a los centros donde se encontraba el dinero y, con su ejemplo y dotes de persuasión, obtuvo recursos abundantes con los que cré lo que hoy llamaríamos un fondo de becas y ayudas universitarias cuya administración tomó a su cargo.

Es lo que constituye la función social del dinero en manos de los que lo poseen y pueden proporcionarlo y, por parte de los beneficiarios, en una recta y competente administración de los bienes recibidos, utilizando los instrumentos propios del sistema económico.

Por otro lado, al beneficio corresponde, en el que lo recibe, la gratitud, siempre presente en Ífíigo en su trato con sus favorecedores ${ }^{165}$. La misma que

165 En su carta desde Paris a Isabel Roser de 10 noviembre 1532, en respuesta a las excusas de ésta de no poderle proveer con mayor abundancia, se expresaba así: «No ay para qué assornar perdón; de la mía temo yo, porque pienso que, si no hago lo que Dios N.S. me obliga por todos mis bienhechores, que su divina y justa justicia no me perdonará; quánto mas con el cargo que de viestra persona tengo ... Assí pensad que, de ay adelante, vuestra voluntad tan sana y tan sincera por mí será recebida tan lleno de plazer y gozo espiritual, como con todo el dinero que enviarme pudiérades; porque más Dios N.S. nos obliga mirar y amar al dador que al don, para siempre tener[le] delante de nuestros ojos, en nuestra ánima y en nuestras entraũas». MHSI EppIgn I, 85 
quedó reflejada en las Constituciones de la Compañfa de Jesús en relación con los fundadores y bienhechores de los colegios ${ }^{166}$.

\section{CONCLUSIÓN}

Para terminar, restaría una cuestión abierta acreedora a un estudio más particularizado: cuál pudo ser la posición de Íñigo de Loyola respecto de la justicia o injusticia de las operaciones mercantiles realizadas por sus amigos y bienhechores de cuyo lucro se beneficiaba. Era una cuestión antigua discutida por los doctores.

Resulta interesante constatar que, en 1532, al año siguiente de la inauguración de la nueva Bolsa de Amberes y de la última visita de íñigo a las plazas del Norte de Europa, los mercaderes españoles de la plaza anversana manifestaron inquietudes de conciencia. Enviaron a París a su confesor franciscano, Fray Juan Baptista, para consultar a los doctores de la Facultad de Teología del colegio de la Sorbona diversos casos sobre la licitud o ilicitud en materia de cambios. Uno de los maestros consultados fue fray Francisco de Vitoria, de la Orden de Predicaborres, futuro profesor de Salamanca, donde alcanzó renombre ${ }^{167}$.

Por otra parte y sin pretenderlo directamente, espero haber también contribuido, con estas notas, a ilustrar un aspecto del mundo de los mercaderes castellanos de Europa del Norte quizás poco estudiado: su vinculación al mundo universitario parisino a través de la incorporación de sus propios vástagos a la Universidad como alumnos y maestros, el mecenazgo financiero respecto de los estudiantes de escasos recursos y la demanda de asesoramiento a los doctores de la Sorbona sobre cuestiones de ética económica que afectaban a sus operaciones, especialmente a las bursátiles. El caso de fiñigo Lopez de Loyola debe inscribirse en el marco de estas relaciones.

166 Constituciones P IV, c. 1: De la memoria de los fundadores y bienhechores de los collegios. A los fundadores y bienhechores de los colegios, la Companía les hace participes de todas sus buenas obras (n. ${ }^{\circ}$ ). En el $n .{ }^{\circ} 6$, se dice «Y generaimente a ellos, y a los que fueren cosa suya, en sus días y después de ellos, téngase la Companfía por obligada especialmente, de obligación de caridad y amor, de hacerles todo servicio que según nuestra mínima profesión se pudiere a gloria divinas

${ }^{167}$ GORIS 507.545

Hispania, del Mediterráneo al Atlántico

Hispania Sacra 51 (1999) 